Historic, archived document

Do not assume content reflects current scientific knowledge, policies, or practices. 



\author{
UNITED STATES DEPARTMENT OF AGRICULTURE \\ Farmer Cooperative Service \\ Washington, D. C. 20250
}

\title{
AN APPRAISAL OF SELECTED FARMER-CONTROLLED \\ FIRMS IN NEW JERSEY'S FRESH FRUIT AND VEGETABLE MARKETING INDUSTRY
}

by

Richard S. Berberich

and

David Volkin 
Farmer Cooperative Service strengthens the economic position of farmers and other rural people by improving organization, development, management, and operation of their cooperatives. It works directly with cooperative leaders and Federal and State agencies on cooperative problems. It publishes research results and educational materials and issues the News for Farmer Cooperatives.

The Service helps (1) farmers and other rural residents get better prices for products they sell and obtain supplies and services at lower cost; (2) rural residents use cooperatives to develop and make effective use of their resources; (3) cooperatives improve their services and operate more efficiently; (4) patrons, directors, employees, and the public to better understand how cooperatives work and benefit their members and their communities; and (5) encourage international cooperative programs.

\section{CONTENTS}

The basic problem and its symptoms.................. 2

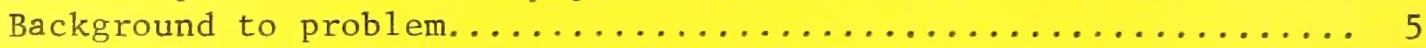

Recommendations for individual association action...........6

Changes needed in marketing pattern of industry............ 10

Cooperative joint sales agency..................... 12

Organizational structure and operating methods of firms in study... 15 Atlantic County Market Growers Association Cooperative, Inc. .... 15 Cedarville Cooperative Marketing Association, Inc. ........... 19 Cooperative Growers Association, Inc. ................. 22 Gloucester County Agricultural Cooperative Association, Inc. ... 25 Hammonton Cooperative Fruit Auction Association, Inc. ........ 29 Landisville Fruit Growers Cooperative Association, Inc. ....... 31

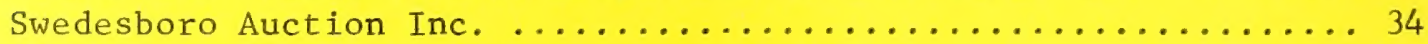
Tri-County Cooperative Market Association Inc. ............. 37

Appendix..................................... 40 


\title{
AN APPRAISAL OF SELECTED FARMER-CONTROLLED FIRMS IN NEW JERSEY'S FRESH FRUIT AND VEGETABLE MARKETING INDUSTRY
}

\author{
by Richard S. Berberich, Crops Division \\ and David Volkin, Cooperative Development
}

Farmers today must meet the needs of mass merchandising and direct buying or be bypassed by others willing and able to do so. We see. increased need for larger and stronger cooperatives to help solve the problems of the market place. As farmer's market power relates directly to the expanding market of large buyers, the required bargaining strength can be met through more effective cooperatives.

Growers of fruits and vegetables must come to realize the necessity of having the type of cooperative which gives them the needed market power in our evolving production and marketing system.

This report appraises the basic problem and its symptoms for eight marketing organizations and suggests changes needed to improve their marketing pattern in relation to the fresh produce industry in New Jersey.

Farmer Cooperative Service (FCS) received requests from seven marketing cooperatives and one farmer-controlled corporation over the period October 10, 1968 through January 15, 1969, for a study to help them improve their organizations, strengthen their market position, and improve members' returns. These organizations saw the need for a more effective marketing program.

Out of discussions with officials of these organizations, staff members from Rutgers University, and the New Jersey Department of Agriculture, we developed a study plan. We appraised the organizational and financial arrangements of the participating firms; proposed ways to improve operations; explored alternative programs -such as coordinated marketing for strengthening firms' marketing position; and measured, where possible, the effect of proposed changes on grower returns. 
We obtained financial and business records for the most recent 5 years and interviewed management to obtain information on organization structure, facilities, operating methods, sales arrangements and outlets, charges and services performed. Because of its confidential nature, the section that discusses the financial condition and operating results for each organization is included only in FCS Case Report No. 321 for limited distribution to officials of the respective organizations.

The eight marketing organizations studied are:

Atlantic County Market Growers Association Cooperative, Inc., Egg Harbor City, N. J.

Cedarville Cooperative Marketing Association, Inc., Cedarville, N. J.

Gloucester County Agricultural Cooperative Association, Inc., Glassboro, N. J.

Cooperative Growers Association, Inc., Bever1y, N. J.

Landisville Fruit Growers' Cooperative Association, Landisville, N. J.

Tri-County Cooperative Auction Marketing Association, Inc., Hightstown, N. J.

Hammonton Cooperative Fruit Auction Association, Inc., Hammonton, N. J.

Swedesboro Auction, Inc., Swedesboro, N. J.

\section{THE BASIC PROBLEM AND ITS SYMPTOMS}

Members of the seven New Jersey fruit and vegetable marketing cooperatives and producers-stockholders of one farmer controlled corporation included in this study can achieve really meaningful economic objectives through cooperative marketing if they solve a basic problem common throughout their organizations: lack of commitment.

The following discussion cites several examples of a need for greater commitment on the part of the associations' management -- both hired and elected.

1. There is a need for commitment to provide equity capital.

A11 but Swedesboro (a noncooperative, primarily farmer-owned stock corporation) are nonstock membership cooperatives with annul membership fees ranging from $\$ 1$ to $\$ 5$. Even these amounts are deducted from the seasons' first payments to producers -- not out-of-pocket grower expenditures. The remaining equity capital are reserves derived from retained savings. 
As a result, members are not generally aware of their financing obligations and the extent they have or have not met them based on their use of their association's services.

\section{There is a need for commitment to redeem allocated capital.}

Managers and directors generally assume that (1) the individual amounts would have little favorable impact on the typical recipient, (2) co-ops would have great difficulty in locating many owners of such equities, and (3) present patrons would prefer using such funds to improve services to producers.

But we disagree with this last assumption in observing another area of need for commitment in most if not all the associations: -- a need for commitment to grow and to improve services. Notable exceptions are: Cedarville with its expansion into improved vacuum cooling and a new pepper packing line and Gloucester County with its move to Mullica Hill.

3. There is a need for commitment by members to patronize their own organizations.

Most grower-members of all the organizations will sell to a buyer or through a broker who offers more pennies on any particular deal than the cooperative can。

Thus, a prerequisite for establishing a sound basis for direct sales to the large buyer -- a steady supply of good, uniform quality, wellpacked produce -- cannot consistently be met by any of the cooperatives. Sadly enough, the lack of commitment to patronize is a failing of many of the associations' directors.

4. There is a need for commitment by boards of directors to adopt sound management practices -- to build strong organizations.

This is evidenced by the failure to use a systematic approach to financial management. As a result, credit extension and collection procedures are loose or nonexistent, there is almost complete rejection of use of financial and operating budgets as planning and performance evaluation tools, and there is a preference for jawbone exhortation rather than carefully prepared cost-benefit analyses and projections to substantiate proposed fixed asset expenditures, new services, or cost savings procedures. 
And we believe the reluctance to use the services of the springfield, Mass。, Bank for Cooperatives stems in part from an aversion to complying with the sound cooperative and business principles espoused by the Bank.

5. There is a need for commitment by boards of directors to the business principle of permitting hired management the initiative and freedom to exercise the how of carrying out a manager's duties with the directors, confining their efforts to policy matters and the evaluation of a hired manager's performance in carrying out policies.

But the deficiency is not completely the fault of the boards. Rather, in our opinion, it lies in some degree in the lack of leadership ability, the lack of vigor, the lack of initiative, ambition and imagination in many of the managers to provide policy direction and carefully analyzed programs couched in terms that a typical board member understands: to wit--how a proposal will benefit his and other members' pocketbooks.

For the most part, the association managers, by failing to provide we11-researched, forward-looking proposals to their boards for consideration, place their boards in a position to react negatively. Thus, the directors are preoccupied with worrying about last month's telephone bill (too much), the cost of labor (too high), and other operating matters that should be the exclusive concern of the hired manager.

6. There is a need for commitment to encourage more complete understanding by members of the objectives of the cooperatives and the operating policies and procedures adopted to achieve these objectives. Some of the organizations have good information that could be quite illuminating to present and potential members -- fairly good operating results and trends, for example. Except for the annual meeting, however, none of the associations use a public relations approach to provide such information. It's as though the less the members know, the better off everybody will be. Thus members feel little if any responsibility to participate in the management of the cooperatives.

7. There is a need for commitment to take an aggressive competitive stance with respect to supply sales and other related services. In some areas, members buy their supplies from brokers for fear that, otherwise, the brokers will pass them by when it comes time to move their produce. 
And there seems to be little interest by hired management in some instances and by board members in others, to explore the possibilities of doing business with urban or surburban patrons -- the lawn and garden phase of the supplies business, for example, as a means of building volume.

Indifference, undue concern about the tax treatment of nonmember business, and unwillingness of farmer patrons to defer to nonfarmer customers contribute to an inertia in developing urban-oriented business.

The cooperatives in many cases are forced into too lenient credit terms as a competitive factor thus ending up as bankers not only to their own patrons but also the buyers of their produce. Agway, Inc., Syracuse, N. Yo, is "just another supplier" which, because of its taut-ship credit terms, is patronized only sparingly by the associations as a wholesale source of supplies. Because the cooperatives believe they must extend lenient credit terms, they in turn seek to do business only with wholesale suppliers who will give them extended terms. (Our mention of Agway does not mean that we hold a special brief for that organization. Rather, because it is a cooperative, ultimate economic benefits do flow to its farmer patrons on a patronage basis. Can we say the same for other than cooperative wholesale suppliers you often patronize?)

\section{Background to Problem}

What is the basis for the need for commitment presented in the foregoing? The Fabian-Burns reports $1 /$ provide substantial documentation to several significant factors and trends. Briefly, their reports document that most growers have the advantage of several competitive marketing outlets; that a substantial sample of members interviewed (74 percent) expressed no desire for a change in their marketing organizations' selling methods.

On the other hand, nonmembers' responses give a distinct impression that they would support a strong central sales agency that had strong membership support and that used membership contracts to assure a power base in bargaining for price and other terms of trade.

1/ The Role of Farmer Owned Fruit and Vegetable Marketing Organizations. A. E. 315 and 316. Rutgers Univ。, New Brunswick, N。J., 1966 and 1967. 
To achieve a strong, powerful bargaining position, New Jersey fruit and vegetable growers must simply get together -- "act in concert" -- become committed to the concept of organizing on a much broader basis for their own mutual benefit. Is the need felt strong enough and the leadership, statesmanship, and sense of obligation within the grower groups of sufficient capacity and dedication to achieve the unity required to do the job?

\section{Recommendations for Individual Association Action}

There will more than likely be some "shakedowns" within this group of eight organizations, as attrition of the smaller producers takes place along with the increasing pace of urbanization with the corollary expansion of other job opportunities. For example, Beverly could liquidate or move to a more productive area. Swedesboro could merge with Gloucester County. Hammonton could liquidate and its producers shift to the other organizations. Hightstown and Gloucester appear to have rather strong financial underpinnings. Atlantic County has questionable membership support. Cedarville has made substantial facility commitments.

The firms in this study are composed of highly fragmented, individualistic groups of producers. At best, these organizations inject a competitive element in the South Jersey market structure for fresh fruits and vegetables. Members take advantage -- both in a positive and negative sense -- of their co-ops' presence in the market to enhance their own--as contrasted to their cooperatives' -- marketing efforts. In doing so, this weakens their joint bargaining strength. The net result is a disadvantage rather than an advantage to individual producers. Their production diversity and varied marketing alternatives do little to encourage a strong unified front to buyers. Pending such time that strong indigenous leadership does emerge, our suggestions are oriented toward the continued existence of the present organizations subject, of course, to the possible changes we alluded to in the preceding discussion.

First, we believe that respective boards should decide whether they want their associations to accomplish something more than just injecting a weak competitive element into the market structure within which their associations operate. If they visualize their cooperatives only as instruments merely to make a little competition, then they must accept the fact that their association will command only the minimum patronage of members to the extent that they believe will make other market outlets competitive. Under these circumstances, members tend to shift their patronage to competitors because, by so doing, they are relieved of the responsibility of financing, patronizing, and participating in the management decision making in their co-ops. 
Thus we observe a minimum membership fee setup, relative ease in becoming a member, and ease in terminating membership. And hired management digs hard for nonmember volume to fill out loads and achieve an economic operation.

On the other hand, if directors and managers visualize adopting a conscious policy of building their organizations into more aggressive, vital, growth-minded competitive business, then they ought to adopt broader objectives -- for example, objectives that would

-- enable members to have the best possible income producing farms, and

- supply their employees with the best possible income opportunities and work responsibilities.

In this situation, a cooperative may require greater member financing and member contracts and embark on involved membership relations programs -- al1 to assure members" patronage. The "urge to merge" will be greater because of the growth that can be attained and the market power that could flow from a successful merger. Patronage refund policies will be important also as a means of getting economic benefits back to producers.

There will be a compelling necessity to increase efficiency -- to gain economies of scale-- to become market oriented. Thus efforts to "go basic," integrate operations, and improve standards will call for greater capital demands on members.

Second, the boards should continually challenge hired management to come up with sound plans and systematic programs that would improve services, increase business volume, enhance members' income and, as a residual benefit, document a sound basis for increased employee benefits and pay.

Third, there is evidence that wiser cash management practices would benefit producers. For example, the buildup of cash and investments in capital stock of other firms during the seasonal low-point of receivables and inventories raises three questions:

a. Have reserves been built up beyond the point where they are "reasonable"? 
b. Should excess working capital be used to redeem equities held by long-suffering and patient equity holders? Such redemptions not only would affirm the concept that the economic benefits of cooperative marketing go to patrons, but also would be a tremendous membership relations gambit.

c. Should the associations seriously consider borrowing seasonal funds to finance receivables and inventories rather than attempting to harbor such funds during the off-season in the form of certificates of deposit or other forms of investment? The organizations' purpose, it should be remembered, is not to invest members' funds. Rather, it is to perform marketing and purchasing functions and related services.

Fourth, New Jersey growers realize the need to gain marketing strength through greater unity. The Fabian-Burns reports point out that over 60 percent of growers interviewed believed that merging all locals or affiliating with a regional or national organization was quite desirable.

This finding confirms what we know to be true in so many situations throughout the country -- that members of cooperatives are much more ready for major changes in the structure and functions of their co-ops than their directors believe to be the case. The New Jersey reports highlight the weaknesses of membership relations of these organizations. Our contacts with these organizations appear to confirm that in too many cases board policies are shaped by personal rather than membership considerations.

Fifth, there is a lack of understanding of the new Federal income tax laws especially as these laws relate to their patrons' tax responsibilities. For example, associations that issue nonqualified written notices of allocation should inform their recipients that these allocations should not be reported as current income. By the same token, associations that issue qualified allocations should inform their recipients that such allocations should be reported as current income. We strongly suggest that the associations take steps to familiarize themselves with both the cooperatives' and their patrons' respective tax responsibilities to avoid both legal and member relations problems。

Sixth, because the minimal membership fee provides a flimsy and casual basis for a producer to either become a member or to terminate his membership, the associations make little, if any, effort to acquaint present and potential members with the "rules of the game" embodied in their bylaws. We suggest as a matter of ordinary cooperative business practice that the associations provide copies of their bylaws to their members. 
More important1y, however, the adoption of such a practice should be preceded by a detailed line-by-line evaluation of such papers to determine if the rules should be changed to conform with actual operations, or if operations should be changed to comply with the rules. This should be done by the directors and hired management, not by an attorney or outside consultant. We believe an educational and eyeopening session would be had by all.

Seventh, we discussed with managers the kind of information they generate internally to enable them to carry out their responsibilities and, in turn, the kind of information they provide to their boards to enable them to carry out their board responsibilities. The responses varied from a "cash activities report," a "trial balance," a "list of receivables," to "monthly balance sheet" and "operating statements" along with schedules of properly aged receivables.

In one case, the manager provided the board with a daily diary briefly summarizing each day's significant events, patrons contacted and the like. Ideally, boards should not only receive reports that provide basic current information, but also should answer such questions as:

How are we doing?

Are we doing better or worse than last year?

Better or worse than expected? Why?

Where does the responsibility lie?

If the New Jersey associations are really serious about adopting a policy of strengthening their business organizations they should, as an important first step, adopt some form of budgetary control. Why? Because preparation of operating and financial budgets forces the board to plan.

Budgets channel and direct the association toward the kind of services growers want. Their preparation provides the realistic basis for a board to clearly see its policymaking responsibilities and hired management its operating and policy implementation duties. In practically all the associations there are examples of the confusion between the board of directors and hired management about their respective duties and responsibilities. 
In one case, a board member has interfered with the manager by entering into salary discussions with employees. In other cases, irate producers ask and get directors to intervene with managers with respect to the movement of and the prices established for their produce. In another case, directors nitpick over the telephone bill or inhibit the purchase or rental of office equipment that is essential to efficient operations.

We suggest, therefore, that the associations adopt and operate under some sort of budgetary control. By using and evaluating comparative periodic balance sheet and operating statements, directors and hired management would: (a) Establish reasonable performance expectations, and (b) be equipped to use logic and reason to the continued challenge of applying knowledge gained from past experience not just to the problems of tomorrow and next month, but also next year and 5 years from now.

Eight, existence of a parent-subsidiary arrangement indicates, among other things, the need for the parent cooperative to go beyond its membership for adequate volume. Another section of this report discusses the possibility of forming a cooperative joint sales arrangement by the firms included in this study.

Finally, some means should be found to improve services to members over that provided by many small brokers. We strongly suggest that the associations use marketing contracts. They would provide legal support and evidence of membership commitment to their cooperatives and thus enable growers to present a solid front to broker-buyers.

\section{CHANGES NEEDED IN MARKETING PATTERN OF INDUSTRY}

The eight organizations face serious problems in marketing programs. They lack the volume of business to be a factor in the market. Their aggregate share of the State's volume of fruits and vegetables has decreased.

Managers receive relatively low salaries, averaging under $\$ 10,000$ a year. There has been little change in salaries over the past decade in spite of the considerable rise in the cost of living. This close monetary policy on wages reflects in part the general decline or stagnation in marketing and services.

In 1968, seven of the eight firms sold produce through the auction method with their combined auction sales totaling less than one-third of the total fruit and vegetable auction sales in New Jersey. In contrast, one relatively large cooperative not included in the study bandled about two-thirds of the total auction sales. 
Two of the cooperatives in the study dropped their auction method of sales in early 1969 and another one is seriously considering such a move.

The mechanics of a successful auction require a sufficient number of buyers and sellers to have the functions of supply and demand operating at a satisfactory price leve1. The buyers require sufficient volume, variety, and quality of produce to warrant their continuing participation. The sellers need an adequate number of buyers to bid up produce at a price in line with the quality of each lot going through the auction block.

Although some of the New Jersey firms are still realizing net margins from their relatively small auction business, most of the air tions show a downward trend in volume and savings over the past decade.

In 1969 three of nine fruit and vegetable marketing firms in New Jersey handling some produce on auction dropped their auction business. One firm went out of business while the other two shifted to a carlot sales program.

An eventual reduction of from six to two auctions could best assure both buyers and sellers participating on the auction block a more economic and efficient marketing operation.

A current problem to adequately deal with some of the large chains and other types of big buyers is attributable to the uncoordinated market structure in the state. Fresh fruits and vegetables are sold by many small cooperatives, noncooperative firms, brokers, and individual farmers who market too limited a volume and variety of produce to attract many of the large buyers.

Furthermore, in a market structure with many sellars and few buyers, sellers are at a distinct disadvantage because they compete against each other for the same buyer or buyers.

There is need for a strong cooperative carlot sales program featuring volume, variety and quality of produce in addition to the auction method of selling. 
Interested cooperatives and farmer controlled marketing organizations should consider selecting a committee consisting of at least one knowledgeable representative from each firm to work out a program for the best type of marketing organization to handle members ' fruits and vegetables. Additional advisory assistance might be supplied by the New Jersey State Department of Agriculture, the Cooperative Extension Service, Rutgers University, and the Farmer Cooperative Service of the U.S. Department of Agriculture.

Success for any marketing organization requires a sound economic plan, determined leadership, and adequate financing from loyal members.

The Fabian-Burns report, A.E。316, includes a section entitled Alternatives for Developing Marketing Power. These alternatives cover merger, and centralized, federated, and combination types of regional associations. Information from reports such as USDA, MRR 826 29 includes considerations in developing a coordinated marketing program could further stimulate the committee in the planning stage. The committee could use these reports for discussion purposes and then pursue their appraisal in depth for the operation needed.

After a tentative decision is reached on the type of organization best suited for the industry, selected personnel should visit the most successful counterparts in the fresh produce industry and study their operations. This experience would assist the group in developing their plan of operation.

\section{Cooperative Joint Sales Agency}

One approach we recommend to interested cooperatives and farmercontrolled firms in New Jersey's fresh fruit and vegetable industry is to establish a cooperative joint sales agency. This type of sales program would enable participating firms to enlarge and strengthen their market position and obtain benefits they could not realize from individual efforts.

Benefits which may be derived from an efficient coordination of marketing functions include lower unit sales and promotional costs, adequate financing by combining resources; better market distribution, more orderly marketing of total production, higher total sales value for production, improved standardization of produce, and reduction in transportation and distribution costs.

2

Richard S。Berberich, Coordinated Marketing Programs of Selected Fruit and Vegetable Cooperatives, Mktg. Res。Rpt。826, U。S. Dept. of Agri., September 1968. 
In belonging to a joint sales agency each member firm would maintain its organizational identity and could continue to operate independently in al1 areas except their participation in the joint carlot sales program.

For example, each member firm would continue to operate an existing auction market as long as it remained economically feasible. We would anticipate that the produce going through the auction would come through members whose products are not under a marketing agreement with the organization. Furthermore any of the member cooperatives in a joint sales program can successfully merge to improve efficiency and achieve maximum economy and still continue their affiliation with the sales agency.

In planning a joint sales agency which includes the diversified selling of produce and handling necessary paperwork for members we suggest setting up distinct departments for sales and accounting. Personnel in these departments would be responsible to the general manager. The general manager, in turn, would be responsible for carrying out the policy directives of the board of directors.

Figure 1 shows a diagram of a proposed organizational plan incorporating these suggestions。

Figure 1。-- Suggested Organizational Structure for a Joint Sales Agency

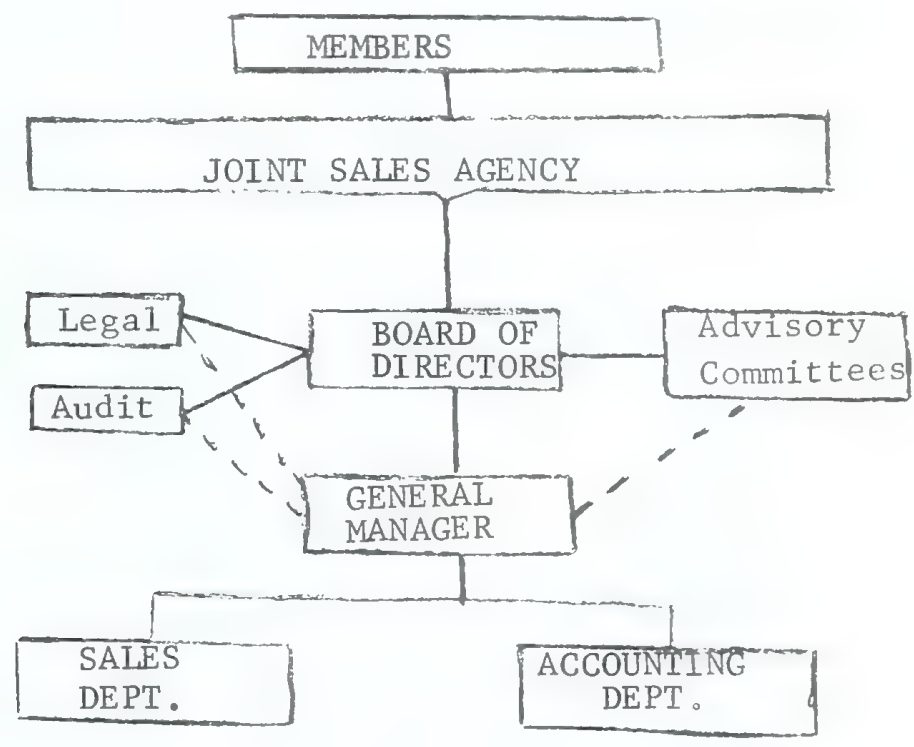

Direct responsibility and reporting

Advisory capacity 
A joint sales agency could be established with a minimum of expense through rental of office space and most of its equipment.

The initial organizational costs and other expenses could be covered through a small assessment to member firms based on the volume of produce they handled in a recent year. This advance should then be set up on a revolving fund basis and returned to members in proportion to their contribution.

The appendix on pages 40 through 65 presents articles of incorporation, bylaws, marketing agreement and membership agreement examples that illustrate in detail the legal and contractual arrangements that could be considered and possibly adopted in establishing a cooperative joint sales produce agency.

The cooperative sales agency would set the price, make the sale and handle the attendant paperwork for its members. Sales could be either pooled or made on an individual lot basis. If handled on an individual basis, each individual could be credited with his own receipts and sales costs prorated on a unit basis.

By maintaining their identity and operating autonomy in all activities except marketing, the members, whether grower controlled firms, cooperatives, or individual farmers, would still be responsible for packing, grading, and storing produce.

Once established the cooperative sales agency could meet operating and sales costs from a deduction of a few cents per carton on all produce handled.

The emphasis for the sales organization should be on competent sales management and sales personnel hired at a competitive price.

The sales agency could be assured of adequate volume and variety of produce through a binding market contract. A key point of the contract should be effective requirements for quality standards and quality control. Acceptance by members of both the letter and spirit of such a legally binding arrangement would indicate a strong commitment to help assure success of a joint sales program.

To help assure success in a sales operation involving fresh fruits and vegetables, the sales representatives would require the latest market information as we 11 as fast communication to prospective buyers. In addition to telephone circuits, the agency should be equipped with a market news service wire and a private wire for personal contracts. Another possibility would be emergency radio service direct to producers' fields。 
The sales agency could be set up to offer a relatively full line of fruits and vegetables in straight or mixed load shipments. It could promote selective distribution of merchandise according to type of market.

We believe that if most of the eight firms in the study are to remain in business, they will have to increase their service functions such as grading, packing, cooling, and storing of produce, and, if needed, handling members production and marketing supplies.

The marketing can be accomplished under a joint sales program by top flight sales personnel with the firms acting as important receiving stations for the designated produce.

\section{ORGANIZATIONAL STRUCTURE AND OPERATING METHODS OF FIRMS IN STUDY}

The fresh fruit and vegetable industry in New Jersey includes a large number of small to medium size farmers, brokers, cooperatives, and noncooperative firms that market a limited volume and variety of produce.

All of the eight firms discussed in this section have one serious problem -- lack of volume. In reviewing the operations of these firms other weaknesses in varying degrees include the quality and variety of produce handled and limitations on services provided members.

\section{At lantic County Market Growers Association Cooperative, Inc.}

Atlantic County Market Growers Association Cooperative, Inc。, (ACMGAC) was organized and incorporated in June 1936. The co-op was formed to grade, pack, store, and market produce and handle a limited quantity of marketing supplies for its members.

In Apri1, 1961, ACMGAC assigned the Atlantic County Market Growers, Inc., (ACMG) a subsidiary corporation, to operate all phases of receiving, packing, and marketing its products on an annual contract.

\section{Organizational Structure and Facilities}

ACMGAC had about 75 members who marketed produce through the organization in 1968. Major buildings are in good condition and include an office, packing and storing facilities, and a cooler.

Major equipment for vegetables such as white potato bagger and tying machine and a sweet potato waxer and bagger line are in fair condition. The cartoning machine and carton filler for blueberries have proven rather unsatisfactory. 
Eligibility for Membership.-- Any producer of agricultural products who is accepted by the board of directors and who pays an annual membership fee of $\$ 1$ can become a member. His certificate of membership continues in effect as long as he complies with the rules and regulations of the association.

Marketing Contract.--The cooperative has an agreement employing the Atlantic County Market Growers, Inc., to market members' produce to the extent orders are available. The cooperative has no marketing contract with its members at the present time. An exclusive marketing agreement in which the member agreed to sell the commodities produced and grown by him through the co-op and its agent, ACMG subject to certain conditions, was discontinued several years ago.

Financing.--Methods of financing used by the cooperative include equity certificates, certificates of indebtedness and loans through the Springfield Bank for Cooperatives.

Board and Management.--The cooperative is controlled by a ninemember board of directors serving for a period of 3 years but on a staggered basis so that three new members are elected each year.

The president and vice president of the cooperative must be elected from the board while the secretary and treasurer need not be. Elections take place at the annual meeting and terms served are for one year.

Special committees appointed by the board include the nominating, auditing, and entertainment committees. The committees normally meet once a year and report their findings to the board of directors.

The directors may hire a market manager to conduct the executive and administrative duties of the association under their direction.

Employees.--ACMG currently handles the receiving, packing, and marketing of the cooperative members' products. Consequently all employees salaries are paid by the corporation.

Full-time employees paid by the corporation include a general manager, head bookkeeper, and a clerk. In addition, 9 to 11 part-time employees are hired for receiving, grading, and packing produce on the association's platform.

Policies.--The cooperative, in conjunction with its corporate marketing agent, emphasized the importance of quality produce to their growers and the services available to them such as washing, grading, cooling, packing, trucking, and storage of produce. Also the need for larger volume and variety of produce is stressed to improve the sales program. 
The cooperative currently stores sweet potatoes for its members and rents its other facilities to the Atlantic County Market Growers Corporation which acts in the co-op's behalf in receiving, packing, cooling, and marketing members' produce. In addition, the corporation handles other than members' produce on a purchase-and-sales basis or consigned basis.

Major crops handled are cabbage, lettuce, white potatoes, peppers, and blueberries. Other crops include squash, cucumbers, sweet potatoes, asparagus, scallions, beans, parsley, eggplant, rhubarb, escarole, and romaine.

Services Provided.-- The cooperative arrangements for members include sale of produce, washing, and grading and packing potatoes and sweet potatoes, vacuum cooling lettuce, icing produce when needed, storage of sweet potatoes and squash, and trucking all produce. Supplies handled for members include containers, staples, and cellophane.

The corporation gives its customers a quality guarantee, loads the produce on trucks, and starts them on their way. When necessary, credit is extended to reliable buyers.

Sales.-- Sales volume has gone down sharply in the past five seasons as shown in the following tabulation:

\begin{tabular}{cc}
\hline Season & Volume of sales \\
\hline Nov. thru October & Dollars \\
$1964-65$ & $\$ 1,557,983$ \\
$1965-66$ & $1,397,860$ \\
$1966-67$ & 699,795 \\
$1967-68$ & 815,488 \\
$1968-69$ & 761,079 \\
\hline
\end{tabular}

Markets Served.-- The principal markets in which produce is normally shipped include Norfolk, Va。; Winston Salem, N。C.; Columbia, S。C。; At lanta, Ga.; and Miami and Tampa, Fla. 
Selling Methods.--Approximately three-fourths of the sales are made direct to wholesalers and corporate chainstores with the balance handled through brokers.

Brand Policy.--Approximately 40 percent of sales are marketed under the Jersey Shore brand. Commodities packed under this label include sweet potatoes, white potatoes, lettuce, cabbage, and blueberries.

A11 other sales packages are marketed under the growers' name or 1 abel.

Market Information.--Principal sources of market information are the USDA Market News Service, State market news service, and phone contacts with brokers.

Quality Control.--The cooperative through its corporate agency has inspection and quality control in packaging and grading both sweet potatoes and white potatoes. The importance of quality control for other crops is stressed to the growers who must assume this responsibility at the farm level.

Operating Problems.--Some of the problems faced by the cooperative and its corporate agency include the need for stronger member participation and support; an overall lack of volume which reduces marketing effectiveness as well as needed revenue for the operation; and a way to convince growers that they must pack their produce according to buyers' specifications.

Management's Appraisal of Sales Situation.--Fewer buyers in the produce market have resulted in more competition and consequently more difficulty pricewise in marketing. Increased varieties specified by buyers present problems in getting the needed produce from other sources. The increase in direct buying helps the sales manager through talking directly to the individual buyers for finalizing sales. Buyers demand for quality produce has assisted sales management because the stress on quality with members has resulted in an improved quality program. 
Cedarville, N. J., Cooperative Marketing Association was incorporated and began operations in March 1928. Basically it operates a vacuum cooling service, performs limited packing and grading of vegetables, and sells a variety of produce for its members.

\section{Organizational Structure and Facilities}

Membership in the cooperative was about 75 growers in 1968. Shortly after World War II membership reached a peak of over 700 and then gradually declined to a relatively low number of members.

The cooperative's board of directors selects the manager and bookkeeper. The manager hires all other employees and is responsible for the sales and service operations.

For bookkeeping purposes, the sales and service operations are kept under separate accounts.

Major buildings are in relatively good condition. These include an office, a packing house shed, and a jet vacuum cooling plant.

Eligibility for Membership.-- A member must be a producer of agricultural products. In addition an annual membership fee of $\$ 1$ must be paid on a member's first sale through the cooperative. Several years ago this annual membership fee was reduced from the original requirement of $\$ 5$.

Market Contract.-- The cooperative has no grower contract at the present time. The feasibility of a contract with member-growers has been discussed and is being considered for the direct sales program.

Financing.-- Methods of financing include use of capital surplus and loans through commercial banks and the Springfield Bank for Cooperatives.

Board and Management.-- The association's board consists of seven directors elected for a 3 year term with the required new members selected at the annual meeting.

The president and vice-president must be elected from members of the board. The treasurer and secretary may be nonmembers.

The general manager hired by the board is responsible for carrying out policy and supervising the overall operations. 
Special comittees appointed by the board are nominating, auditing, and service committees. The nominating comittee appraises the nominations for directors, the auditing committee reviews the auditor's report, and the service committee assists the board on policy decisions in the sales and service programs.

Employees.-- The cooperative currently has a full-time general manager. The part-time employees are a bookkeeper, a clerk, and seasonal workers to handle produce packing and miscellaneous work as needed. Before 1969 the cooperative also employed an auctioneer and two men to handle produce at the auction on a seasonal basis.

Policies.-- The objective of the sales program is to convince growers of the need for quality produce to obtain satisfactory prices and to stimulate an increase in sales through the cooperative.

The cooperative plans to expand its services to members. An enlargement of its vacuum cooling facilities and its grading and packing program for peppers are recent steps in this direction.

\section{Operations}

The cooperative's sales and service operations are handled by the general manager and clerical personnel at the office in Cedarville.

Major crops sold through the cooperative are snap beans, lettuce, onions, squash, and strawberries. Other crops include lima beans, cabbage, cucumbers, and peppers.

Services Provided Members.-- Since early 1969, the auction market has been discontinued and all produce sales handled through the cooperative are either direct or through brokers.

The cooperative has begun an expanded program on vacuum cooling of produce and recently installed a grading and packing service for cucumbers.

Sales.-- The cooperative's produce sales volume has declined drasti$\overline{c a l l y}$ over the 5 years (1965-through 1969 seasons) as shown in. table on the next page. 


\begin{tabular}{cl}
\hline Season & Volume of sales \\
\hline
\end{tabular}

Nov. thru. Oct.

1964-65

1965-66

1966-67

1967-68

1968-69
Dollars

$\$ 611,014$

655,813

407,917

241,444

179,066

During this period of reduced produce sales the volume and profitability of the cooperative's vacuum cooling service showed a considerable increase that helped the cooperative obtain a net savings from its operations in four of the five seasons.

Markets Served.--All sales prior to 1969, with the exception of a small amount to the Government were sold on the auction block. The major part of this produce went to New York and Philadelphia. Other markets included Baltimore, Washington, Providence, and Boston.

Selling Method.-- Beginning in 1969 the method of sales is principally through brokers and direct to chain stores.

Brand Policy.-- The only label used on produce handled through the auction which operated until 1969 was the family or farm name on the seller crates. Sales other than auction is a recent innovation with no brand policy developed as yet.

Market Information.-- Management receives market information by phone through brokers and from Bridgeton, through State and Federal market news reports。

Quality Control.-- The cooperative exerts some quality control for cucumbers that are packed under their supervision. Any other quality control for produce would be at the farm level.

Operating Problems.-- Management indicates the need for increased volume in sales as well as additional services to obtain added revenue for a successful operation. Operating costs have already been reduced to a minimum. 
Management's appraisal of sales situation.--Fewer buyers has made sales more difficult in terms of generating competition for most satisfactory price. At times crop growing conditions have not been conducive to meeting quality demands. The cooperative also has problems to meet demands for increased varieties of produce specified by buyers due to limitation of supplies available in the area. Demand for consumer size packages cannot be met because of a relatively short season and high cost of packaging.

\section{Cooperative Growers Association Inc.}

Cooperative Growers Association at Beverly, N。 J., is the oldest marketing organization in the study. It was incorporated as a cooperative in October 1918. It sells members' produce through the auction, direct, and on consignment; handles production and market supplies; and grades, hydrocools, ices, trucks, and stores produce.

\section{Organizational Structure and Facilities}

The overall membership in 1968 was about 150 growers. On the average, only about one-fourth of the members' produce was handled through the cooperative.

The general manager carries out the policies of the board including supervising purchasing, sales, and employees of the association. The board of directors hires a salesman to handle the direct sales program for corn.

Buildings include an office, warehouse, auction platform, and cold storage room. They are considered adequate for the current size of the operation.

Eligibility for Membership.-- A member must be a local grower of produce who will comply with the bylaws, rules, and regulations of the association, and pay an annual membership fee of $\$ 5$.

Marketing Agreement.-- There is no marketing agreement between the cooperative and its member growers in auction, direct, or consignment sales.

Financing.-- Methods of financing used include patrons equity and loans through commercial banks.

Board and Management.-- The cooperative's policy is set by a board of nine members elected for 3 years on a staggered basis so that three new members are elected at each annual meeting. Officers of the association are elected from members of the board. 
The board is responsible for hiring a general manager and a sales manager for the direct sales of corn.

Committees selected by the board include the legislative, finance, personnel, building and grounds, action, auditing, nominating, purchasing, New York shipping, auction, and direct sales of corn.

Each committee studies specific problems in its area and recommends findings to the board of directors.

Employees.-- The cooperative employs a general manager and a bookkeeper full time. Part time employees include a salesman, auctioneer, and 15 to 20 people for miscellaneous duties such as unloading and loading the trucked-in corn for hydrocooling.

Policies.-- The objective is to increase the sales volume of produce through the cooperative as well as to expand production and marketing supplies for a better quantity discount.

The board encourages the manager to approach farmers as prospects for joining the cooperative. In addition, monthly newsletters are distributed to new and potential members advising them of the cooperative's available services.

\section{Operations}

The cooperative operates a sales and supply program for its members.

A variety of vegetables and some fruits are handled through auction and consignment sales. The direct sales program is limited to corn but accounts for about 40 percent of the total sales volume.

Major produce handled are sweet corn, tomatoes, and peaches。 Other crops handled include apples, lima beans, snap beans, cantaloups, cucumbers, eggplant, onions, peppers, potatoes, and squash.

Services Provided.-- The cooperative sells its members' produce, grades, hydrocools, and truckscorn, hydrocools, trucks and stores peaches; and trucks all other produce handled on consignment. Production supplies handled for members include fertilizers, chemicals, seed, and lime. Marketing supplies consist of containers for members' produce.

Buyers of auction produce receive a quality guarantee based on the samples shown at the sale.

The cooperative has State inspection on direct sales of corn to insure the buyer of quality produce. 
The cooperative permits credit extension of 10 days to established buyers with a good credit rating and if warranted, a reasonable allowance after this period.

Sales.-- Dollar volume in special sales dropped below $\$ 400,000$ in the 1968-69 season for the first time in the 5 years beginning with the 1964-65 season. Auction sales in the same period continued downward as shown below.

Season : Auction sales : Special sales I/ : Total sales

\begin{tabular}{ccrr} 
Nov. thru. Oct。 & Dollars & Dollars & Dollars \\
& $\$ 76,746$ & $\$ 441,543$ & $\$ 518,289$ \\
$1965-66$ & 66,562 & 428,522 & 495,084 \\
$1966-67$ & 36,930 & 476,177 & 513,107 \\
$1967-68$ & 38,092 & 420,235 & 458,327 \\
$1968-69$ & 14,962 & 355,698 & 370,660 \\
\hline II A11 sales other than auction. & \\
\hline
\end{tabular}

Markets Served.- Sweet corn is shipped to North Carolina, South Carolina, Georgia, and Florida under the direct sales program. All other produce is principally marketed in the New Jersey area and on consignment to Hunts Point, N. Y。

Selling Methods.-- The major part of the cooperative's produce sales go direct and on consignment in about equal amounts with only a limited volume handled on the auction block.

Brand Policy.-- Several years ago the cooperative tried the Jersey Bel1 brand name for its corn sales. It was not continued. Currently there is no brand utilized in the program.

Promotional Arrangements.-- The cooperative's sweet corn is advertised in the Packer and Produce News for the direct sales program. In addition some overall advertising is handled by the Cooperative Marketing Association of New Jersey. The manager of the cooperative also runs a few ads on production supplies in the local paper.

Market Information.-- The cooperative receives market information from the Federal and State market news by telephone from Bridgeton, N. J., various trade journals, and market quotations from New York and Philadelphia. 
Quality Contro1.--The cooperative has State inspection for all corn in the direct sales program. Quality control for all other produce is the responsibility of the growers at the farm level.

Operating Problems.--The basic problem is lack of volume. Both the produce sales and supply program would need a sizable increase in volume to assure the cooperative a profitable operation.

Management's Appraisal of Sales Situation.--The firm's opinion is that better cooperation is needed by both the directors and members in selling their produce and buying supplies through the cooperative.

Management believes that both the increase in direct buying and fewer buyers have made their selling problems more difficult.

Gloucester County Agricultural Cooperative Association, Inc.

Gloucester County Agricultural Cooperative at Glassboro, N. J., was established and incorporated as a cooperative in March 1933. It markets fresh fruits and vegetables through the auction for its members, sells farm supplies, and operates storage facilities.

Organizational Structure and Facilities

About 450 people were listed as members in 1968, but only about 200 were considered as fairly active participants. Policy formulated by the board is carried out by the general manager. He is responsible for the supervision of the sales, supply, cold storage, and office and accounting departments.

Major buildings include an office and supplies building, auction and storage facilities at Glassboro and cold storage and freezer facilities at Pitman.

The co-op's buildings at Glassboro are in good condition. However, cold storage and freezer facilities at Pitman are in fair to poor condition.

The cooperative has recently purchased a new site at Mullica Hill and will eventually have all new facilities and operations at this location. 
Eligibility for Membership.-- Membership is open to persons producing agricultural products who pay an annual membership fee of $\$ 1$ and patronize the association.

Marketing Contract.-- The cooperative had a marketing contract with members for its direct sales program on peaches which expired at the end of the 1966-67 season. Currently the cooperative se11s on $1 \mathrm{y}$ on auction and has no marketing contract with members 。

Financing.-- The cooperative's financing has been through equity certificates, capital surplus, commercial banks, and the Springfield Bank for Cooperatives.

Board and Management.-- The board of nine members is elected for 3 years on a staggered basis so that 3 new members are elected at each annual meeting.

The president, vice-president, and treasurer must be elected from members of the board; the secretary need not be.

The four committees are supply, cold storage, auction, and finance. The function of each committee is to meet periodically, study the departments it is responsible for, and recommend findings to the board of directors.

The board hires the general manager who is responsible for carrying out policy, hiring employees, and supervising the operations.

Employees.-Full-time employees include a generai manager, two salesmen, two engineers, two warehouse supply men, two clerks, and a secretary. In addition, the cooperative hires about 52 seasonal or part-time employees for work in their office, supply, cold storage, and auction programs.

Policies.-- The cooperative encourages quality produce at the auction by having a Federal inspector available during the sales period. Auction samples are representative of total produce for sale.

Another objective is to increase the sales of production and marketing supplies by offering volume discounts. The cooperative hopes to increase its membership through supplying good services to growers at one centralized location.

\section{Operations}

The cooperative has its programs divided into separate departments such as supply, marketing, and cold storage to provide an effective delegation of authority and accountability within each area of activity. 
Major crops handled through the auction are peaches and tomatoes. Additional crops include cantaloups, peppers, eggplant, apples, and blueberries.

Services Provided.-- The cooperative currently sells its members produce through the auction, hydrocools peaches and miscellaneous vegetables, and stores peaches, apples, and turnips.

Currently the cooperative serves its members with a variety of supplies such as lime, fertilizer, packages, and chemicals at both the Glassboro and Mulica Hill warehouses.

Buyers at auction are given quality guarantees on basis of produce samples. These buyers are given the opportunity to look over the produce at the auction and demand inspection if any question arises relating to the sample procedure.

Credit extension is only given to reputable buyers when absolutely needed.

Sales.-- Total produce sales improved in the 1968-69 season and were the highest since 1964-65. As the direct sales program was discontinued in 1968 this recent sales increase was a result of the highest auction sales in the past 5 years.

\begin{tabular}{|c|c|c|c|}
\hline Season & Auction sales & Special salesI/ & Total sales \\
\hline Nov, thru Oct. & Dollars & Do11ars & Dollars \\
\hline $1964-65$ & 898,051 & 457,584 & $1,355,635$ \\
\hline $1965-66$ & 770,874 & 369,748 & $1,140,622$ \\
\hline $1966-67$ & 706,302 & 167,591 & 873,893 \\
\hline $1967-68$ & 877,132 & - & 877,132 \\
\hline $1968-69$ & $1,157,732$ & - & $1,157,732$ \\
\hline
\end{tabular}


Markets Served.-- Produce purchased by brokers at the auction are shipped to the New York area, Philadelphia, and other nearby points as well as to Canada. Purchases by roadside market operators are largely confined to the New Jersey area.

Selling Methods.-- All produce sales currently move through the auction. In 1968 the cooperative discontinued its direct sales program for peaches which had been in operation for about 9 years.

Brand Policy.-- The cooperative had a Jersey Bell brand for its direct sales peach program until 1968. Under the auction program a few of the grower-members pack under their own label, but the co-op has no brand of its own.

Market Information.-- Methods used by the cooperative in obtaining market information, include reports from Federal and state market news, trade journals, and by the phone from market information service at Bridgeton, through brokers and market contacts at Hunts Point, N。Y。

Quality Control.-- Basically, quality control of produce for the auction sales is performed by growers on their farms. However, availability of the inspector at the auction helps farmers realize the importance of quality in relation to price when the buyers look over the samples.

Operating Problems.-- The cooperative's business is too far flung for efficient supervision of a general manager. In addition, the cold storage facility at Pitman is obsolete and inefficient. These problems should be corrected on completion of the centralized operation at Mullica Hill which will include a new cold storage building, and facilities for sales and purchase.

Management's Appraisal of Sales Situation.-- Management believes that the overall increase in direct buying has hurt their auction sales to some extent. Fewer buyers at the auction make it more difficult pricewise for growers selling their produce.

The cooperative also believes it should supply more service to buyers to gain their good will. 
The Hammonton Cooperative Fruit Auction, Hammonton, N. J., was incorporated and began operations in July 1935. It sells its members' produce on auction, performs a cooling, freezing and cold storage service for members' fruits, storage for sweet potatoes, and supplies containers for members' berries.

\section{Organizational Structure and Facilities}

In 1968 the cooperative had 130 members. About 75 percent of these members marketed from half to all of their produce through the cooperative. The remaining members average patronage was only about 25 percent of their total produce.

The general manager hired by the board of directors is responsible for carrying out policy and supervising all cooperative activities.

The cooperative's buildings are in fair to good condition and include an office, auction shed, loading shed, freezer and cold storage facility, and a sweet potato storage building. Major equipment consists of truck scales and fork lift truck and pallets.

Eligibility for Membership.--A producer of agricultural products who markets some of his produce through the cooperative and pays an annual fee of $\$ 2$ may be admitted as a member. However, the board of directors has the authority to reject any application for membership.

Marketing Contract. - The cooperative currently has no marketing contract with its members. Their last marketing contract was tied in with a direct sales program involving blueberries. This was discontinued in 1966.

Financing. - The cooperative's method of financing has been through equity certificates and capital surplus.

Board and Management.--The board of directors, consisting of nine members. controls the co-op's business. Members are in office for 3 years. The original nominations were staggered in 1-, 2-, and 3-year terms so that three new members are elected each year.

The president and vice-president must be elected from members of the board; the secretary and treasurer need not be.

A committee is appointed each year to make arrangements for the annual meeting.

The board hires the general manager who carries out policy decisions, supervise the operations, and hires employees as needed. 
Employees. - A general manager and clerk are hired full-time. Part-time employees include a bookkeeper, clerk, auctioneer, platform man, two package boys, and a watchman.

Policies.--The policy of the cooperative is to obtain the best price possible for members' produce handled through the auction and to stress the importance of quality in relation to prices received. Storage facilities and supplies are offered to members under the cooperative's policy to meet prevailing commercial rates.

\section{Operations}

The general manager is in charge of the cooling, freezing, and storage operation. He also handles supplies for members and supervises the auction sales.

Services Provided Members.--The cooperative sells its members' berries through the auction and provides cooling and freezing service for members' produce, cold storage for peaches, and controlled storage for sweet potatoes. In addition, the cooperative supplies containers, cellophane wrappers, and rubber bands to members.

Sales.--Although auction sales of produce showed only a small decline over the 5 years ending October 1969, the discontinuance of the direct sale program on blueberries in the 1966-67 season resulted in a substantial decline in total sales of produce as shown below.

\begin{tabular}{|c|c|c|c|c|c|}
\hline Season & $:$ & Auction sales & $\begin{array}{l}: \\
: \\
\end{array}$ & Special sales $1 /$ & : Total sales \\
\hline Nov. thru Oct. & & Dollars & & Dollars & Dollars \\
\hline $1964-65$ & & 650,805 & & 685,805 & $1,336,610$ \\
\hline $1965-66$ & & 607,426 & & 652,119 & $1,259,545$ \\
\hline $1966-67$ & & 536,373 & & -- & 536,373 \\
\hline $1967-68$ & & 589,443 & & -- & 589,443 \\
\hline $1968-69$ & & 581,943 & & -- & 581,943 \\
\hline
\end{tabular}

I'Al1 sales other than auction.

Markets Served.--The major markets for the produce purchased off the auction include New York, Boston, Syracuse, Pittsburgh, Cleveland, Baltimore, and Washington, D. C. 
Selling Methods.--About three-fourths of the auction sales are to brokers and commission merchants with the balance going to roadside market operators.

Brand Policy.--Up until 1966 the cooperative handled the direct sales of the Atlantic County Blueberry Association including the trade name "Blue Crest." Currently the cooperative has no brand or label in its auction sales program.

Market Information.--The cooperative receives market information from Federal and State market news service, by telephone from Bridgeton, N. J. and from radio stations, trade journals, and newspapers.

Quality Control.--Any quality control of produce is the responsibility of the grower who sells his merchandise at the auction. The growers are made aware of the importance of quality produce by the pricing system relying on buyers judgement of samples on auction.

Operating Problems.--There is need for a closer relationship between buyers and directors, management, and members of the cooperative.

At times there are collection problems after the manager applies the regulations established by the board for extending credit to customers. Additional volume of produce is needed for a continued profitable operation.

Management's Appraisal of Sales Situation.--The increase in direct buying has made management problems more difficult because it has resulted in a lower auction volume of sales. Also fewer buyers at the auction tend to create an atmosphere conducive to lower sales prices. The limited variety of product at the co-op's auction loses some members participation who have sufficient variety of produce to sell through a larger auction with many buyers.

\section{Landisville Fruit Growers Cooperative Association, Inc.}

Landisville Fruit Growers Cooperative Association at Landisville, N. J., was organized and incorporated as a cooperative in May 1934. It handles production and marketing supplies for its members, grades and packs sweet potatoes and cucumbers, stores sweet potatoes, and selis members' produce through local brokers.

\section{Organizational Structure and Facilities}

The cooperative had about 210 members in 1968. The members either marketed their produce or purchased supplies through the organization.

The general manager, appointed by the board of directors, is currently responsible for the supply program and sales of members' produce. He is also in charge of the packinghouse operation.

Major buildings are in fair condition and include an office, two sweet potato storage facilities, a packinghouse shed, and a supply warehouse.

Eligibility for Membership.--Membership is on a yearly basis. The requisites for an individual membership is to pay a fee of $\$ 1$, grow and market some produce through the cooperative, or purchase supplies through the organization. 
Marketing contract. - The cooperative has no marketing contract with its members. Consequently the amount and percentage of produce marketed through the co-op varies considerably among the membership.

Financing.--Methods of financing that have been used include equity certificates, capital surplus and loans through the Springfield Bank for Cooperatives.

Board and Management. - The business of the association is controlled by a board of directors consisting of nine representatives elected for 3 years on a staggered basis so that three new members are elected each year.

The president, vice-president, secretary, and treasurer of the association are elected from members of the board.

The board is responsible for hiring a general manager to implement their policies through day to day decisions.

Employees.--Ful1-time employees include a general manager, a bookkeeper, and a warehouseman. Approximately 12 to 15 part-time employees are hired to pack sweet potatoes and cucumbers.

Policies.--Current policies of the cooperative are to develop sales to local brokers, handle production and marketing supplies, and perform grading, packing, and storage services. The objective is to perform these services for members on the basis of competitive prices.

\section{Operations}

The operations of the co-op are divided into marketing, packing and storage, and purchasing departments. These departments are handled by the general manager and his bookkeeper at a central office in Landisville. Records for each department are separately maintained for accounting purposes and to better appraise operational results.

Major crops handled are peppers, lettuce, cabbage, cucumbers, and eggplants. Other crops include tomatoes, escarole and endive, beets, onions, spinach, broccoli, and strawberries.

Services Provided Members.--In addition to selling its members' produce, the co-op grades and packs their sweet potatoes, peppers, and cucumbers and has storage facilities for sweet potatoes. Supplies handled for members include containers, fertilizers, chemicals, and seeds.

When necessary, members are extended credit up to 20 percent of their previous year's sales. 
Sales.--The following tabulation shows the cooperative has had some major fluctuations but no definite trend in produce sales volume over the 5-year period ending October 1969.

\begin{tabular}{cc}
\hline Season & $:$ Volume of Sales \\
\hline Nov. thru Oct. & $\frac{\text { Dollars }}{1964-65}$ \\
$1965-66$ & $1,026,140$ \\
$1966-67$ & 704,140 \\
$1967-68$ & 768,546 \\
$1968-69$ & 719,679 \\
\hline
\end{tabular}

Markets Served.--Most of the produce purchased by brokers from the cooper?tive is shipped to Boston, New York, Pittsburgh, Philadelphia, and Washington, D. C. Some produce is distributed as far as Canada.

Selling Methods.--Management's current method of sales is to local brokers. Sales through the auction method were discontinued in early 1969.

Brand Policy.--The cooperative has no brand or label of its own. Produce is marketed under members' names or labels.

Market Information.--The general manager of the co-op obtains market information from various sources, including trade journals, Federal and State market news, and local brokers.

Quality Contro1.--The cooperative's personnel regulate the quality of growers' cucumbers, peppers, and sweet potatoes that are packed at the association's warehouse. Quality control for all: other produce is the responsibility of the member growers. If a buyer desires State inspection for produce up for sale, he must assume the additional costs.

Operating Problems. - The major problem facing the cooperative is the decline in their sales volume. The current size of the operation makes it difficult for the cooperative to meet fixed expenses.

Management's Appraisal of Sales Situation.--The trend toward fewer buyers makes it more difficult to promote sufficient sales competition for a satisfactory price. The limited volume and variety of produce handled by the cooperative presents problems in filling certain orders. 
Swedesboro Auction Inc., Swedesboro, N. J., a íarmer-controlled noncooperative corporation, was established in May 1938. The corporation sells growers' fresh produce through the auction block and contracts acreage of asparagus for processing with farmers and then prepares it for delivery to a processing plant.

\section{Organizational Structure and Facilities}

The corporation served 182 farmers and 62 buyers who marketed or purchased some produce through the Swedesboro Auction in 1968.

Stockholders of the corporation appoint the board of directors. After the annual meeting of stockholders, the board elects the officers of the corporation. The board is also responsible for hiring the general manager.

Buildings include an office, auction block, loading platform, and a buyers office and supply room.

Eligibility for Membership.--To be a member with voting privileges of one vote an individual must be a farmer or commission merchant doing business with the corporation and hold one share of common stock.

Marketing Agreement. - The corporation has no marketing agreement with its members on produce sold at auction. However, it does act as an agent for a processor in contracting asparagus acreage for processing.

Financing. - Methods of financing, is primarily through retention of tax-paid surplus.

Board and Management. --The corporation's policy is controlled by a ninemember board of directors serving on a 3-year staggered basis so that three new members are elected each year by the stockholders. All directors at the time of their nomination and election must be stockholders doing business with the Swedesboro Auction Inc.

The president and vice-president must be elected from the board while the secretary and treasurer need not be directors.

Special committees appointed by the board include the operating, buyers, and maintenance committees. The operating committee has responsibility for analyzing operations and recommending methods for improvement; the buyers committee investigates any defaults in payments by buyers as well as exploring possible changes to better accommodate buyers; and the operating committee is concerned with maintenance of existing buildings and recommendations for new facilities.

The general manager hired by the board carries out their policies, supervises employees, and handles the necessary day to day operating decisions. 
Employees.--The corporation employs a general manager and a bookkeeper full time. An auctioneer, clerk, two men on the auction block, and a woman accountant for the asparagus processing program are hired as parttime employees.

Policies.--The objective of the corporation is to encourage growers to market their fresh produce through the auction by striving for the best possible price and to accommodate buyers in terms of volume and quality of produce and services rendered.

The corporation, through mediation with the processor and growers, works for an equitable annual contract on asparagus acreage.

\section{Operations}

The corporation normally handles over 400,000 packages of produce annual1y through its auction and between 1 and 1.5 million pounds of asparagus for the processor in its marketing operation.

Major produce handled are asparagus, tomatoes, and green peppers. Other produce include mixed and red peppers, eggplants, cantaloupess and a variety of miscellaneous vegetables.

Services Provided.--Growers patronizing the Swedesboro auction are paid on an individual account basis for their produce on the first Thursday after the week of the sale.

The corporation contracts with farmers for asparagus acreage, performs some quality supervision, and then weighs, inspects, and supervises delivery of the produce to the processing plant.

The corporation guarantees the quality of produce to buyers at auction based on samples displayed and also extends credit to reliable customers if absolutely necessary.

Sales.--Total value of auction sales has shown an upward trend in the past 5 years ending 0ct. 1969 as indicated below.

\begin{tabular}{cc}
\hline Season & :Volume of auction sales \\
\hline Nov. thru Oct. & Dollars \\
$1964-65$ & $1,278,194$ \\
$1965-66$ & $1,393,619$ \\
$1966-67$ & $1,351,427$ \\
$1967-68$ & $1,714,925$ \\
$1968-69$ & $1,731,178$ \\
\hline
\end{tabular}


Markets Served.--Principal markets served by the auction buyers include Newark, New York, Philadelphia, Chicago, Boston, Pittsburgh, Cleveland, and Miami.

Selling Methods.--Volume of sales through auction are about 80 percent to brokers, 10 percent to roadside market operators, and 10 percent to chains.

Brand Policy.--The corporation has no brand or label of its own. A11 produce sold at auction is crated under the farmers' names or labels.

Market Information.--Sources of market information include telephone contacts with dealers on the produce markets and State and Federal market news reports.

The manager sees that farmers served by the auction who request market information are informed by telephone and placed on the mailing list for market news information.

Quality Contro1.--Management tries through educational efforts to assist growers in improving quality of their produce. Basically, however, quality control is the responsibility of the growers at the farm level.

Operating Problems.--One basic problem is the need for an increased volume of auction sales to assure the corporation of a more profitable operation.

As the corporation has rather 1 imited services it performs for the local farmers some additional services could add revenue and might also encourage increased grower participation at the auction.

Management's Appraisal of Sales Situation.-- The Manager indicates that producers of a single crop like asparagus should consider banding together and limiting the quantity for sale on the fresh market based on price considerations. The balance of the volume could be kept off the commercial market or diverted to processing outlets. This procedure could be accomplished through a marketing agreement and order.

Management believes that the increase in direct buying has hurt the volume of their auction sales. Also fewer buyers reduce competition, and higher quality standards tend to weaken the demand by the more discriminate buyer for the lower quality produce. 
Tri-County Cooperative Market Association at Hightstown was organized and incorporated as a cooperative in January 1933. Basically, it sells members' produce through the auction, although a small quantity is handled through direct sales. Another service includes sales of baskets and crates to members.

\section{Organizational Structure and Facilities}

Membership totaled about 350 in 1968. Although all members are required to sell some of their produce through the cooperative, the average quantity handled by the cooperative is only about 25 percent of the members' total volume.

The board of directors sets the overall policy for the cooperative. It is the responsibility of the manager to carry out the board of directors' program which includes supervision of all operations.

Major facilities utilized are in good condition. These include the office, auction block, platform shed, and potato building. The cooperative also has an egg building and two refrigerated coolers currently leased out.

Eligibility for Membership.--Requirements for membership include an annual fee per member of $\$ 5$ and active participation in the production and marketing of agricultural commodities through the cooperative.

Marketing Contract. - The cooperative has no marketing contract with its members. Growers who are members apparently want a free rei in the disposition of their produce.

Financing.--Methods of financing include use of capital surplus and equity certificates.

Board and Management.--The cooperative has a nine-member board of directors. The 3-year term of office is staggered so that three new members are elected each year.

At the members' annual meeting, the board of directors elect a president and vice-president who must be members of the board and a secretary and treasurer who need not be in the association. The board also appoints a general manager who is responsible for conducting the executive and administrative duties of the association.

Committees appointed by management include auditing, finance, membership, land and building, policy, and fruit and vegetable. 
Employees.--Ful1-time employees are the general manager, secretary, bookkeeper, and auctioneer. Seasonal employees include a clerk typist, sales clerk, and four workers who help unload produce and set up samples at the auction platform.

Policies.--The objectives of the cooperative are to obtain a consistently good price for growers' produce, increase the volume handled, and stress the importance of quality in relation to price.

Management is striving to increase membership and interest larger producers in a direct sales program of a size to attract volume buyers.

\section{Operations}

The cooperative operates an auction sales program, se11s a sma11 quantity of produce direct, rents out storage space, and handles baskets and crates for its members.

Major produce handled consists of tomatoes, apples, peaches, sweet corn, peppers, cabbage, cucumbers, squash, and white potatoes. Other produce include asparagus, lima beans, snap beans, beets, cantaloupes, cauliflower, egg plant, lettuce, onions, strawberries, and other berries.

Services Provided.--The cooperative handles its members' produce principally through auction sales and sells marketing supplies such as baskets and crates to growers at a competitive price.

Al1 buyers are given quality guarantees on auction sales based on produce samples. Any sales adjustment must be made before produce is hauled from premises.

Although most sales are cash, the cooperative does permit credit extension of 10 days to good customers when needed.

Sales.--Auction sales increased in the 1968-69 season but otherwise showed relatively minor fluctuations, while the limited volume of special sales remained at a negligable amount over the 1964-65 through 1968-69 seasons as shown below.

\begin{tabular}{|c|c|c|c|c|c|c|}
\hline Season & : & Auction sales & : Special & sales $\underline{1}^{\prime}$ & $\begin{array}{l}: \\
:\end{array}$ & Total sales \\
\hline Nov. thru Oct. & & Dollars & Do1 & 1 ars & & Dollars \\
\hline $1964-65$ & & 467,766 & &, 432 & & 473,198 \\
\hline $1965-66$ & & 477,880 & & 778 & & 478,658 \\
\hline $1966-67$ & & 447,462 & &, 902 & & 451,364 \\
\hline $1967-68$ & & 493,979 & & 374 & & 494,353 \\
\hline $1968-69$ & & 543,371 & &, 245 & & 545,616 \\
\hline
\end{tabular}


Markets Served.--Over 90 percent of the sales volume is marketed in the New Jersey area with the balance going to New York and Philadelphia.

Selling Methods.--In recent years, over 98 percent of the cooperative's produce sales were handled through the auction with the balance going direct.

Brand Policy.--The cooperative currently uses no brand or trade mark in their marketing of produce. Formally they marketed white potatoes in 100 -pound bags under the Tri-County brand.

Market Information.--The cooperative obtains market information by telephone from the State news service at Bridgetong from the Federal and State market news reports, and from Farm Bureau and other farmer organizations.

Quality Control.--A11 quality control for produce is the responsibility of the growers. However, the importance of quality is discussed at the cooperative's annual meetings.

Operating Problems.--Some of the problems involve keeping a good relationship between the buyers and sellers of produce at the auction and maintaining the correct management balance between the board, general manager, and key employees. At times the cooperative experiences difficulty in getting adequate labor for seasonal work.

Management's Appraisal of Sales Situation.--The increase in direct buying in the area has caused some loss of auction sales for the cooperative. Also the trend toward fewer buyers at the auction reduces competition. and makes it more difficult price wise for the seller. The cooperative handles a large variety of produce which helps induce enough buyers at the auction to maintain a satisfactory price level. 


\section{APPENDIX}

The articles of incorporation, by-laws, marketing agreement, and membership agreement examples presented in the following appendixes are intended to illustrate in detail the legal and contractual arrangements that could be explored and possibly adopted in establishing a cooperative joint sales produce agency. However, professional legal advice is recommended in the actual development and adoption of the legal arrangements.

Appendix A - Example of articles of incorporation for a cooperative joint sales produce agency.

Appendix B -- Example of by-laws for a cooperative joint sales produce agency.

Appendix C -- Example of a marketing contract between a cooperative joint sales produce agency and member.

Appendix D -- Example of a vegetable cooperative association membership agreement delegating harvesting, packing, and selling functions to the cooperative. 
ARTICLES OF INCORPORATION

$\underline{\mathrm{OF}}$

We, the undersigned, as growers and associations of producers of perishable fruits and vegetables in the State of New Jersey, voluntarily associate ourselves together for the purpose of forming a non-profit cooperative marketing corporation by virtue of the provisions of an act of the Legislature of the State of New Jersey, entitled "An Act to provide for the incorporation and regulation of cooperative agricultural associations, either with or without capital stock" approved February 28, 1924.

FIRST: The name of this corporation shall be

SECOND: The corporation's purposes are:

(a) Primarily to provide a marketing and sales organization for perishable agricultural commodities produced by its members.

(b) To engage in any business or activity related to the purposes described in clause (a) and from time to time authorized or provided by the Board of Directors of this corporation.

THIRD: The principal office for the transaction of the business of the corporation shall be at , in the county of

State of New Jersey.

FOURTH: The number of directors of this corporation shall be This number may be changed by By-Laws adopted by a majoriny of the mombers or by an amendment to such By-Laws approved by a majority of the members.

The names and addresses of the persons who are to act in the capacity of directors until the selection of their successors are as follows:

Name

Address 
FIFTH: The voting power of each member in the corporation shall be equal but in the case of any partnership, corporation, or association which is a member of this corporation, said partnership, corporation or association shall be considered a single member and shall possess no greater voting right than a single member.

IN WITNESS WHEREOF, the undersigned and above-named incorporators and first directors of this corporation have executed these Articles of Incorporation on 197 .

\author{
Appendix B \\ Example of By-Laws for a Cooperative Joint \\ Sales Produce Agency \\ BY-LAWS OF
}

ARTICLE 1.

General Purpose and Operation

This corporation sha11 be hereinafter referred to as "Association." This Association shall be conducted as a non-profit cooperative for the benefit of its members. The primary purpose shall be to provide a marketing and sales organization for perishable agricultural commodities produced by its members.

\title{
ARTICLE 11.
}

\section{Directors and Officers}

Section 1. The business of the Association shall be controlled by a Board of Directors of , each of whom shall be a member of this Association, or duly qualified representatives of members, if other than individuals. 
Section 2. Election of Directors. The term of office of a director shall begin immediately upon his election at the annual meeting of the membership. Each director shall hold office until his successor is elected at the annual meeting of the Association, or until he withdraws from membership, becomes disqualified or is removed from office, whichever shall first occur.

Section 3. Election of Officers. The Board of Directors shall meet within ten (10) days after first elected and within ten (10) days after each annual election, and shall elect by balloting a President, Vice President, Secretary and Treasurer, each of whom shall hold office until election and qualification of his successor, unless earlier removed by death, resignation, or for cause.

Section 4. Vacancies. Whenever a vacancy occurs in the Board of Directors other than from expiration of a term of office the remaining directors shall appoint a member satisfactory to the member represented by the vacated directorship to fill the vacancy until the next regular meeting of the members.

Section 5. Board Meetings. In addition to meetings mentioned above: regular meetings of the board of directors shall be held at such other times and at such places as the board from time to time may determine.

Section 6. Special Meetings. A special meeting of the Board of Directors shall be held whenever called by the President or by a majority of the directors. Any and all business may be transacted at a special meeting. Each call for a special meeting shall be in writing, signed by the person or persons making the same, addressed and delivered to the Secretary, and shall state time and place of such meeting. Upon signing of a waiver of notice of meeting, a meeting of the Board of Directors may be held at any time.

Section 7. Notice of Board Meetings. Notice of regular or special meetings of the Board of Directors shall be mailed to each director at least four (4) days prior to the time of such meeting or by personal delivery of notice at least six (6) hours prior to the time of such meeting, or by personal telephone call to each director at least six (6) hours prior to the time of such meeting, provided that at the time of such personal delivery or telephone call said director is within one hundred (100) miles of the place where said meeting is to be held.

Section 8. Compensation. Members of the Board of Directors shall receive no compensation for their services.

Section 9. Quorum. Two thirds of the Board of Directors shall constitute a quorum for any meeting of the Board. 


\section{Duties of Directors}

Section 1. Management of Business. The Board of Directors shall have general supervision and control of the business affairs of the Association and shall make all rules and regulations not inconsistent with law or these By-Laws for the management of business and guidance of the members, officers, employees, and agents of the Association. The Board shall have power to appoint an executive comittee and such other committees as the Board may determine and may delegate such authority to such committee or committees as it determines to be proper.

Section 2. Employment of Manager. The Board of Directors shal1 have the power to employ or authorize employment of a manager and such other employees as may be deemed necessary and to fix their compensation. The manager shall have charge of the business of marketing the produce of members of Association under direction of the Board of Directors.

Section 3. Audits. At least once in each year the Board of Directors shall secure the services of a competent and disinterested certified public accountant who shall make a careful audit of the books and accounts of Association and render a report in writing thereon, which report shall be submitted to members of the Association not later than 100 days after the calendar year for which said report was rendered. This report shall include at least a balance sheet showing true assets and liabilities of the Association and an operating statement for the year under review.

Section 4. Agreement with Members. The Board shall have the power to enter into contracts. with members for the purpose of marketing produce of the members. In this connection it is a requirement of membership that every member market through the Association all specified produce owned or controlled by said member within the State of New Jersey. Such agreement may provide for liquidated damages, penalties or forfeitures on the part of members in the event said marketing contracts are violated. The Board of Directors shall have power to carry out all agreements of Association with its members in every way advantageous to Association representing members collectively.

Section 5. Depository. The Board of Directors shall have power to select one or more banks to act as depositories of the funds of Association and to determine manner of receiving, depositing, and disbursing funds of Association.

Section 6. Membership Certificates. The Board of Directors sha11 cause to be issued appropriate certificates of membership.

Section 7. The Association shall have the power to sue for, settle, or compromise any claims with respect to produce handled by Association. 
Section 8. The Board of Directors shall have the power to conduct hearings and determine whether or not a member charged with violating the terms of the marketing agreement, the Articles of Incorporation, or the By-Laws has, in fact, so violated said terms and the Board of Directors shall further have the power to levy such penalties or forfeitures as are provided by the Articles of Incorporation, these ByLaws, the marketing contract, or the laws of the State of New Jersey.

ARTICLE IV.

\section{Duties of Officers}

Section 1. The officers of the Association shall be a President, Vice President, Secretary and Treasurer, together with any other administrative officers which the Board of Directors may see fit in its discretion to provide for by resolution entered upon its minutes.

Section 2. The President. If at any time the President shall be unable to act, the Vice President shall take his place and perform his duties; and if the Vice President shall be unable to act, the Board shall appoint a director to do so. The President or such Vice President or director:

1. Shall preside over all meetings of the members and directors.

2. Shall sign, as President, all certificates of membership, and all contracts and instruments which have been first approved by the Board of Directors.

3. Shall call the directors together whenever he deems it necessary and shall have, subject to the advice of the directors, direction of the affairs of the Association and shall generally discharge such other duties as may be required of him by these By-Laws or by the Board.

Section 3. Secretary. It shall be the duty of the Secretary:

1. To keep a record of the proceedings of the meetings of the Board of Directors and of the members.

2. To keep the corporate seal and the book of blank membership certificates, and countersign all certificates issued, and affix said corporate seal to all papers requiring a seal.

3. To keep a proper membership book, showing the name of each member of the Association, the number of his membership certificate, the date of issuance, surrender, cancellation, forfeiture or transfer. 
4. To execute and sign contracts, notes, papers, and documents.

5. To discharge such other duties as pertain to his office or may be prescribed by the Board of Directors.

Section 4. Treasurer. It shall be the duty of the Treasurer:

1. To receive and deposit all funds of the Association, to be paid out only on checks drawn as hereinbefore provided, and account for all receipts, disbursements, and balance on hand.

2. To furnish a bond in such form and in such amount as the Board of Directors may from time to time require.

3. To discharge such other duties as pertain to his office or may be prescribed by the Board of Directors.

\section{ARTICLE V.}

\section{Duties of Manager}

Section 1. In general, under direction of the Board of Directors, the manager shall have general charge of the business of the Association, which principally will be the sale of produce of members. These sales shall be conducted pursuant to a sales policy determined by the Board of Directors and designed to provide an equal opportunity to all members for the marketing of their produce.

Section 2. Manager shall deposit all money belonging to Association which comes into his possession in name of Association in banks selected by Board of Directors and if authorized to do so by Board of Directors shall make all disbursements by check therefrom for ordinary and necessary expenses of business in manner and form prescribed by Board of Directors. Upon appointment of his successor, manager shall deliver to him all money and property belonging to Association which he has in his possession or over which he has control.

Section 3. Manager shall be required to maintain his records and accounts in such a manner that the true and correct condition of business may be ascertained therefrom at any time. He shall render annual and periodical statements in form and in manner prescribed by Board of Directors. He shall carefully preserve all books, documents, correspondence, and records of whatever kind pertaining to the business which may come into his possession.

Section 4. Subject to the approval of Board of Directors, manager shall employ, supervise, and dismiss all agents and employees of Association not specifically employed by Board of Directors. 
Membership

Section 1. Qualifications for Membership. Members shall be limited to persons, firms, partnership, corporations or association, including other cooperative marketing associations, engaged in the production of perishable agricultural commodities handled by the Association, who have executed the marketing contract and have met such other conditions as may be prescribed by the Board of Directors.

Section 2. Application for Membership. Each person who has signed the Articles of Incorporation shall automatically be entitled to a membership for himself or for the corporation, partnership, or association which he represents. Any other person eligible for and desiring admission for membership shall file an application for admission in such form and containing such information as the Board of Directors shal1 prescribe.

Section 3. Acceptance of Application. The Board of Directors shal1 receive applications for membership, and refer such applications to the membership at a meeting thereof duly and regularly called. Affirmative vote by three-fourths (3/4th) of the membership shall be required for acceptance of a new member.

Section 4. Representative Membership. If a member of the Association be other than a natural person, such person may be represented, from time to time, by any associate, officer, manager, or other designated agent, duly authorized in writing so to act who, while so acting in such representative capacity, shall be entitled to have and to exercise all rights, privileges, and authority of membership in Association, including the right to hold any office, including that of Director.

Section 5. Membership Certificates. The Association shall issue certificates of membership to each member upon admission to membership in such form and comtaining such provisions as the Board from time to time may determine.

Section 6. Membership Incapable of Transfer. No certificate of membership can or shall be assigned, either voluntarily or involuntarily or by operation of $1 \mathrm{aw}$, nor can any membership or membership rights or property rights of a member in Association be assigned, transferred, alienated, or encumbered in any manner, or by any means whatsoever.

Any purported or attempted assignment, transfer, alienation, or encumbrance of either the certificate of membership, or of the membership, or membership or property rights shall be wholly void and confer no rights upon the purported assignee, transferee or claimant, unless and until such transfer has been unanimously approved by all then existing members. 
Section 7. Any member who fails to produce any perishable agricultural commodities for sale by Association for a period of twelve (12) consecutive months shall Iose his right to vote or nominate a director until such time as he resumes production of such commodities for sale by the Association. In the event a period of twenty-four (24) months shall elapse without the production of any such commodities for sale by Association his membership shall terminate as provided in Section 8 of this article.

Section 8. Termination of Membership. Membership in the Association may be terminated:

(a) As and whenever the member ceases to be eligible for membership under the provisions of the cooperative marketing laws of the State of New Jersey applicable to this Association or the Articles of Incorporation and By-Laws of the Association;

(b) by death;

(c) by withdrawa1; and

(d) by expulsion.

(a) In the event a member at any time ceases to be eligible for membership, as herein required, the membership theretofore held shall ipso facto terminate upon the adoption of a resolution of the Board of Directors so stating, or appropriate entry of record in the membership records of Association, under authorization of the Board of Directors.

(b) Any membership theretofore held shall ipso facto terminate upon the death of a member. However, the Board of Directors in their discretion may allow the estate of the deceased member to continue as a member during probate and settlement of the deceased member's estate.

(c) Any member shall be permitted to withdraw from membership at any time by filing a written resignation with the Secretary of the Association. Membership will terminate on the date on which such resignation is so filed.

(d) Any member may, for failure to comply with the By-Laws or the rules and regulations of Association, or because of the quality or nature of the vegetables grown by such member, or for such other cause or reason as the Board shall deem sufficient, be expelled from membership by resolution adopted by a three-fifths (3/5th) vote of all members of the Board and confirmed by sixty (60\%) percent of the membership present at the next regular annual meeting, or any special meeting called for such purpose. 
Section 9. Effect of Termination. Termination of membership shal1 release a member of all his obligations as such, but shall not release the member from debts owed to the Association or from contracts to deliver crops to the Association for the calendar year during which. such termination is effective.

Section 10. Member's Rights upon Termination. In the event of termination of membership, regardless of how terminated, Association shall not become, or be liable for the payment of any amount to the member whose membership is terminating, as the value of the property interest in the Association of such person, and each member is received into membership upon the express agreement on the part of such member that the value of the property interest in the Association (prior to dissolution of the Association) shall be nil.

The foregoing provisions are not for the purpose of penalizing any person whose membership shall become forfeited, or otherwise terminated, but rather because no membership will have any real, intrinsic value, it being intended that the Association shall conduct its business (aside from processing and other charges made at cost) with moneys withheld from the Revolving Fund, and said withheld moneys shall be repayable in accordance with the provisions hereof, regardless of the termination of membership.

Section 11. Voting Rights and Powers. No member shall vote more than one vote, and where any member belongs to a partnership which is also a member, or acts as a representative of a member other than a natural person, such member shall vote only one vote and shall designate whether he is voting on his own membership or on the partnership membership or in his representative capacity. If he shall vote as a member, nothing shall preclude the partnership of which he is a member from casting a vote by another of the partners, nor shall the non-natural member which he represents be precluded from voting through some other properly designated representative. Proxy voting sha11 not be permitted.

Section 12. Rights of Members of Original Partnership. Each partner in each and all of the partnerships which are and were original members of this Association at the date of its incorporation shall have and does have the right to become a member of this Association as an individual whenever the original member copartnership of which he is a partner is terminated and dissolved. 
Section 1. The annual meeting of the Association shall be held at a piace to be designated by the Board of Directors in the City of , County of

on the day of , State of New Jersey,

o'clock if not a legal holiday, but if a legal holiday, on the next business day following, for the purpose of electing Directors and transacting such other business as may come before the meeting.

Section 2. Special Meetings. Special meetings of the members for any purpose or purposes whatsoever, may be held upon call made by the President or by the Board of Directors, or by not less than fifteen (15\%) percent of the members, and at a time appointed therefor by those calling the meeting. Call for meeting shall state the time, place, and purpose for which the meeting is held.

Section 3. Notice of Meetings. Written notice of meetings, whether regular or special, shall be sent or given to each member entitled to notice at least three (3) days before the meeting. Notices of special meetings shall state the time and place of meeting and the purpose for which called.

Section 4. Quorum. Fifty-one (51\%) percent of the members of the Association shall constitute a quorum for the transaction of business at any meeting of the members.

Section 5. Presiding Officer. The President and Secretary of Association shall act as Chairman and Secretary, respectively, of such meeting of the members or Board of Directors, unless the meeting shall otherwise decide.

Section 6. Rules for Election and Voting.

(a) The Board of Directors may make and, from time to time change, rules and regulations for the conduct of elections or any election and for voting upon or with respect to any question or matter submitted to the members for vote, consent or assent, except election of Directors and acceptance of new members.

(b) At the annual meeting or at such other meeting at which the election of Directors shall take place, the presiding officer shall call for nominations of Directors. Each member shall have the right to nominate one director either at the time of meeting or in writing 
delivered to the Secretary prior to meeting. The director so nominated by each member shall be automatically elected to office. In the event the required number of directors shall exceed the number of directors so elected, nominations shall be made by members and after the nominations have been closed, the director shall vote upon the remaining directors to be chosen. At such election each member may vote for as many more directors as there are directors to be chosen, but may not cumulate his vote. If there has been nominated for the office of director more than the additional number to be elected, then upon the demand of any member, the election shall be by written ballot; otherwise it shall be viva voce.

\section{ARTICLE VIII.}

\section{Capital}

Section 1. Revolving Fund. The Board is authorized to require members to pay an amount determined by the Board to be sufficient to cover the original organization expense and the initial operating expense: The Board is further authorized to require each member to pay some part of the proceeds of sale of produce by the Association. These payments shall be provided for in the Marketing Contract between member and Association. The amounts so collected shall be used by the Association for organization and operating expense and any capital expenditure determined by the Board. This shall be designated as the Revolving Fund. At the end of each calendar year an account sha11 be made of the amounts collected from members and added to the Revolving Fund and the amount thereof which has been used in the operation of the Association. In the event the Board determines that it is necessary, a portion of the balance may be set aside to finance operations in the succeeding year and the remainder shall be distributed among the members in the same proportion as the payments of each bear to the total payments.

Section. 2. Evidence of Assignment. No assignment or transfer of any Revolving Fund credits, whether voluntary or involuntary, shall be of any effect as against the Association or entitle the assignee or transferee to be paid or to receive any moneys from the Association unless and until evidence satisfactory to the Association of such assignment or transfer be submitted to the cooperative.

Section 3. No Assignment While Indebted to the Association. No assignment or transfer of any Revolving Fund credits, whether voluntary or involuntary, by act of law or otherwise, can be made, nor will any purported assignment or transfer be of any effect against the Association so long as the party whose interest is to be assigned or transferred is indebted to the Association in any manner or for anything, 
whether such indebtedness be liquidated or unliquidated, due or not due; and the Association may withhold consent to and refuse to recognize or be bound by any assignment or transfer, whether voluntary or involuntary, so long as any indebtedness or liability subsists; and the Association shall have and is given a prior lien upon and against the Revolving Fund credits of any member or person to secure any indebtedness or liability to the Association from such member or person, with the right to offset the same against any moneys becoming payable in respect to said credits.

Section 4. Association relies upon own records. In making payment of the indebtedness represented by any Revolving Fund credits, the Association may rely absolutely upon its own records and shall not be Iiable to any person other than the person appearing by its records to be the owner thereof or entitled to payment.

Section 5. Dissolution. In the event of dissolution or winding up of the affairs of the Association no money of the Association representing Revolving Fund credits shall be distributed to members until the liquidation of all assets and all other indebtedness of the Association have been paid, or its payment adequately provided for.

Section 6. No Segregation of Funds. The moneys representing the Revolving Fund credits may be commingled with and used for corporate purposes, as other moneys belonging or coming to the Association; and nothing herein contained shall be deemed to require that any specific moneys or funds be physically segregated, or designated, or marked, or set apart, or held for the Revolving Fund, nor shall the Revolving Fund be deemed a trust fund held for the owners of the Revolving Fund.

\section{ARTICLE IX.}

\section{Miscellaneous}

Section 1. Amendments. These By-Laws may be amended or repealed or new By-Laws adopted in any of the following ways, to-wit:

1. By the vote of at least three-fifths (3/5th) of the Directors, subject to 2 and 3 below at all times.

2. By vote of three-fourths (3/4th) of the members at a meeting thereof, whether special or annual.

3. By written assent of three-fourths $(3 / 4$ th) of the members filed with the Secretary. 
Section 2. Lien. The Association is hereby given a first lien upon al1 funds, property, property rights, and interests in its possession belonging to a member, as security for the repayment to the Association of any and all sums owing to the Association at any time from such members.

Section 3. No Liability to Creditors. There shall be and is no personal liability on the part of the members to creditors of the Association.

Section 4. Revolving Funds Subject to Rights of Creditors. Irrespective as to any other provision herein contained, or as to how created, evidenced or certified, all money, property, and assets representing Revolving Fund credits or credits in any other special fund or funds, created pursuant to these By-Laws, while held and retained by the Association shall be subject to the rights and claims of creditors of the Association, and to the payment of its debts, liabilities, and obligations, and may be hypothecated, mortgaged, or pledged, all in the same manner and to the same extent as any unallocated funds or properties.

Section 5. Dissolution and Liquidation. In the event of dissolution of the Association and winding up of its affairs all moneys and properties of the Association shall be deemed general assets to be distributed and applied as follows:

(a) In payment of all debts, liabilities and obligations of the Association.

(b) Any residue thereafter remaining shall be distributed to the members in the same proportions as the payments previously made by each member under the provisions of these By-Laws and/or any marketing contracts between the Association and its members bears to the total payments made by all of such members during the preceding two (2) calendar years.

Section 6. Separability Clause. If anything contained in these ByLaws be contrary to law, as the same now exists, or any other law subsequently adopted, then such part shall be eliminated or be deemed amended accordingly, but the remainder shall stand. 
Example of a Marketing Contract Between a Cooperative Joint Sales Produce Agency and "Member"

\section{MARKETING CONTRACT}

THIS CONTRACT, made and executed in duplicate between the , a cooperative marketing association, with its offices and

principal place of business at designated as "Association", and as "Member",
, New Jersey, herein , herein designated

\section{WITNESSETH:}

WHEREAS, Association is a cooperative marketing coiporation organized under the laws of the State of New Jersey, permitting and regulating such corporations, and Member is a bona fide member of Association with numerous other members, and

WHEREAS, it is the object and purpose of Member and other members of Association to have Association act on a non-profit basis as the sole marketing agency for all specified produce grown, owned or controlled by Member and other members of Association in the State of New Jersey, and such other produce as Member or other members may elect, and

WHEREAS, this contract is made pursuant to and implements the Articles of Incorporation and By-Laws of the Association (which by this reference are incorporated herein and made a part of this agreement), and it is the intent of Member and all other members that Member shall be entitled to benefits accruing to Member pursuant to this marketing agreement only as long as Member remains a member of the Association and continues to comply with the Articles of Incorporation and By-Laws of the Association and the terms of this marketing agreement.

NOW, THEREFORE, IT IS AGREED BETWEEN ASSOCIATION AND MEMBER AS FOLLOWS:

I. This contract, the Articles of Incorporation and By-Laws of Association are to be interpreted, construed and applied together as fixing and determining rights and privileges of the parties hereto, and a breach of this contract by either party shall subject such party to such liability and penalty as may be provided herein or be provided by the By-Laws of Association.

II. Member agrees as follows:

1. To deliver to Association all specified produce grown, owned or controlled by him, grown in the State of New Jersey which is suitable for marketing purposes during the entire term of this contract, and furnish Association such information as Association may request as to number of acres planted, time, and location of planting. 
2. To properly prepare all crops of such produce for marketing, according to State and Federal grade and packing rules and regulations in force during current year for production and marketing of any season's crop; if any special pack or crating be required by Association to conform to any marketing regulation, Member shall comply therewith upon being advised thereof.

3. That he has not heretofore contracted to se11, market, consign, encumber, or deliver any specified produce subject to this agreement to any person, firm or corporation, except as noted at the end of this agreement, and that he will not hereafter do so during the term of this agreement; that all of his specified produce suitable for marketing, otner than so noted, shall be sold through and delivered to Association for its handing and marketing thereof.

4. If Member transfers in any manner all or any part of the produce subject to this agreement to any person, firm, corporation or association without this Association's prior written consent thereto, such transfer in violation of this agreement shall nevertheless be deemed entirely subject to this contract and the transferee or transferees of the produce shall be obligated to deliver such produce under terms of this contract, the same as Member would have been required to do hereunder. If transferee fails or refuses to do so, Association may maintain against transferee any action or proceeding it might have maintained against Member under the provisions of this contract, the Articles of Incorporation or By-Laws of Association, or the laws of the State of New Jersey, and in the event it brings a suit in a court of law, Association shall be entitled to recover all its costs and disbursements and such attorney fees as the Court may adjudge reasonable from Member and/or transferee or transferees.

5. In the event Member desires to mortgage any crop covered by this contract, he shall immediately give written notice to Association and before giving such mortgage, obtain permission of mortgagee for Association to handle the crop in accordance with the terms of this Agreement. Said mortgage shall provide that all charges or payments to be made by Member for operating expenses, revolving fund or otherwise shall be paid from the sale proceeds of said crop and the Association shall have priority over the Mortgagee to the extent of such charges and payments.

6. Member agrees to pay Association, to cover its operating and sales costs, cents ( ) per carton of produce for all produce to be sold by the Association under the terms of this agreement, which amount will be deducted from net proceeds of sale by Association. Net proceeds shall be defined as proceeds of sale after all transportation, refrigeration, and other charges including commission and/or brokerage shall have been deducted from proceeds of sale. 
Except that where proceeds of sale are less than transportation or other charges hereinabove mentioned against a shipment, Member shall be liable to Association for such deficit but not for payment to cover operating and sales costs of Association. Not later than eight (8) months after the end of calendar year, Association will determine its actual operating costs per carton of all produce sold during theyear and to the extent that the amount paid by Member during the year exceeds Member's pro rata share of that actual cost, this excess shall be refunded to Member. The amount to be paid may be changed from time to time by Association upon action of its Board of Directors.

7. Inasmuch as remedy at law would be inadequate and inasmuch as it is now and ever will be impracticable and extremely difficult to determine actual damage resulting to Association should Member fail so to deliver all of his specified produce, Member agrees to pay to Association for all of this produce delivered, sold, consigned, withheld or marketed by or for him other than in accordance with terms hereof, the sum of twenty (20c) cents per carton, or its equivalent, as liquidated damages for breach of this contract, al1 parties agreeing that this contract is one of a series dependent for its true value on adherence of each and all Members to each and all of said contracts.

In the event it is impossible or impracticable to determine the number of cartons withheld, Member will pay in lieu thereof a liquidated damage of $\$ 100$ per acre or portion thereof. This provision for liquidated damages is in addition to all other remedies for breach provided in Paragraph 4 or elsewhere in this agreement, or by the laws of the State of New Jersey.

\section{Association agrees:}

1. That it will use its best efforts to handle, sell, and deliver produce of Member so that Member may derive best possible results from the sale of his produce. In so selling such produce Association shall have sole discretion as to how and in what manner produce is sold, except that Association will sell produce of Member impartially with produce of like quality, kind, grade, and classification delivered to it by other grower members of Association under contract similar to this, and will obtain best prices it can under market conditions, taking into consideration also marketable condition of Member's product. Nothing provided herein shall prevent Member from having a representative in the coolers to show his produce to Buyers who are selecting produce to be purchased from Association, nor from discussing with potential buyers the purchase of Member's produce through Association.

\section{IT IS MUTUALLY AGREED:}

1. That Association shall determine the price at which produce of Member, and all other members under contracts similar to this, shall be sold. 
2. That Association shall issue bill of lading in Association's name on all shipments; that Association shall assume reponsibility for specifying the routing, type of refrigeration, diversions in transit and all traffic matters; that any transportation claims or claims for allowances filed for or against the Association shall be handled by Association. Association and Member agree to cooporate in the handing of all claims.

3. That Association shall handle and assume the responsibility for invoicing and collections with respect to all shipments.

4. All credit loss sustained on any sale shall be assumed by Association; credit loss being defined as inability of buyer to pay.

5. That inasmuch as Association is a cooperative marketing Association, now operating andhereafter to be operated without profit to Association and the benefits to be derived from its operation and the cooperative marketing of produce accrue entirely to its members, a breach hereof by Member is, therefore, of vital detriment and damage to other members of Association who have contributed their proportionate share of costs and expenses connected with operation and maintenance of the Association in reliance on Member bearing his proportionate share of such costs and expenses. For these reasons, failure of Member to comply with the Articles of Incorporation and/or By-Laws of the Association or any of the terms of this agreement shall, at the option of Association, work a complete forfeiture of the membership of Member and all of his rights and privileges as such Member, and cause forfeiture and cancellation of any and all advances and loans by him to the Association together with all accumulations to his credit in any fund of the Association including revolving or other reserve funds, provided that he be fairly adjudged guilty of failure to comply in form and manner called for by the By-Laws of Association.

6. This contract shall become effective shall run for a period of three (3) years, provided, however, that Member may cancel this agreement at the end of any calendar year by written cancellation notice delivered to Association on or before December I.

7. On or before the 1 st day of 197 or upon execution of this agreement, whichever is later, Member shall pay Association an amount equal to one-half cent $(1 / 2 \xi)$ per carton of produce grown, owned or controlled by Member during the 19 _produce season in the aforementioned portion of the State of New Jersey, which sum shall be an advance by Member to cover organizational and other costs and expenses of Association prior to collection of monegs to be deducted from proceeds of sales as hereinabove provided. For the purpose of providing additional funds for 
organizational and other initial expenses of the Association, it is agreed that on demand Member will either pay to the Association or endorse and guarantee a note or notes of the Association in an amount equal to one (1c) cent per carton of produce grown, owned or controlled by Member during the 19 _ season in the aforementioned portion of the State of New Jersey. Said advances to Association shall be credited to Member's account for the 19 _ season and sha11 be refunded at a time determined by the Board of Directors.

8. Execution of this agreement by Member shall constitute an application by Member for membership in the Association, if Member has not already been accepted as such Member, and execution of this agreement by the Association shall constitute acceptance by the Association of the Member for membership in the Association. Member agrees hereby to furnish all information required of Member by the board under the provisions of the By-Laws of the Association, and Member agrees to be bound in all respects by the By-Laws of the Association.

IN WITNESS WHEREOF the parties hereto have set their hands this day of , 197_.

By

Association

By

Member

Appendix D

Example of a Vegetable Cooperative Association Membership Agreement Delegating Harvesting, Packing, and Selling Functions to the Cooperative

THIS AGREEMENT, made and entered into this , by and between day of a non-profit marketing association, hereinafter called the Association, and 
In consideration of mutual obligations contained herein and in the bylaws of the Association, and in the desire of the parties hereto for the intelligent cooperative harvesting, packing, marketing and selling of agricultural produce with other growers,

\section{IT IS HEREBY AGREED AS FOLLOWS, TO-WIT:}

1. The Grower herein represents that he is the lessee or owner of certain farm lands, and that he will plant or grow upon said land the crops described in the Appendix attached hereto.

2. The Grower does hereby make and appoint the Association his sole and exclusive agent for the harvesting, packing, and selling of all the crops described in the Appendix hereto grown and to be grown for the term of this agreement.

3. The Association agrees to act as agent for the Grower in the harvesting, packing, and selling of all crops described in the Appendix hereto in accordance with the terms hereinafter provided.

4. The Association shall have the sole discretion in determining the time for harvesting, and shall have sole discretion in determining priority of harvesting as between crops grown under this agreement and crops grown under other similar agreements.

5. The Association agrees to dispose of said crops at the best price available to the Association under market conditions and at such times and places and upon such terms and conditions as the Association shall in its conclusive judgment deem for the best interests of the Grower.

6. The Association shall pay to the Grower the net proceeds from the sale of crops. Net proceeds shall be the net excess received over and above the estimated costs herein provided and from time to time fixed by the Association, the "retain", and such other charges as the Association shall have paid or be required to pay in the interest of the Grower in marketing said crops.

7. The Association shall fix an estimated cost, which shall be determined not later than amount thereof shall be made to the Grower by mail. Said estimated cost shall be fixed so that it will cover actual cost, as defined in paragraph 11, below. The Association may, upon notice, increase or decrease the estimated cost provided for herein. The aforesaid estimated cost shall be deducted before paying net proceeds to the Grower. 
8. In addition to the aforesaid estimated cost, the Association shall deduct a sum to be determined by the Association in accordance with the provisions of Article of the By-Laws of this Association, which sum shall be known as a "retain" and for which the Association sha11 issue revolving fund credits or other evidences of indebtedness in accordance with Article _ of the By-Laws of this Association. Said sum to be deducted as a "retain" shall be determined not later than , and notification shall be made to the Grower by mail. Said sum may be increased or decreased by the Association upon days' notice in writing to the grower.

9. The net proceeds shall be remitted to the Grower promptly after making the deductions provided for herein.

10. At the end of the year, or at any specified other period or periods to be determined by the Association from time to time in which said crops are sold, actual costs will be determined by the Association. Any excess of estimated costs over actual costs will be paid to the Grower.

11. The term "actual costs" shal1 mean and be determined as follows: Charges and expenses of every kind incurred or expended by the Association in harvesting, transporting, delivering, receiving, handiing, inspecting, grading, packing, processing, financing, storing, insuring, preserving, selling, or in performing any act, or rendering any service in respect to Grower's crops, and also Grower's share of the Association's general operating, maintenance, and over head expenses, including interest and reasonable reserves for depreciation, obsolescence, bad debts, and such other reserve purposes as are usually recognized by good accounting practices excluding capital reserves and expenditures in the nature of capital investments.

In determining the actual costs for each kind and class of crop, the Association shall pool charges and expenses among the various crops in such a manner that the same actual costs shall apply to a11 crops of the same kind and class grown within one crop district, but that different actual costs shall apply to crops of the same kind and class grown in different crop districts, when such difference is found on good accounting practices.

12. "Bad Debts" shall include but not be limited to:

(a) A11 credit losses sustained by the Association in the handling of produce for Growers which shall be absorbed by the Association as part of its actual costs in the particular year in which said credit losses sha11 occur. 
(b) Losses on all produce consigned by the Association for Grower which does not return its actual cost as fixed for the particular year in which said produce is consigned. The Association shall absorb the difference between the amount received on the consignment of said produce and the actual cost as part of said actual costs in the particular year in which produce is consigned.

In the event at any time there shall be any transportation claims or any other subsequent recoupment on said produce so consigned as to which the Association shall have absorbed losses for Grower as provided in (a) or (b) above, the transportation claims and other recoupments shall belong to the Association to the extent of the losses absorbed by it for the Grower.

Notwithstanding any losses as aforesaid in (a) or (b) above, Grower shall nevertheless be liable for and pay to the Association the "retain" in effect in the particular year in which the said loss shall occur in accordance with paragraph 8.

13. Any excess of actual costs over estimated costs fixed herein or from time to time fixed by the Association will be paid by the Grower to the Association in cash on demand.

14. Receipts of the Association from top ice and/or vacuum cooling patronage dividends shall not inure to the benefit of the specific Growers, but shall inure to the benefit of the Association and shall be used for the reduction of actual costs.

15. If in the opinion of the Association the market or the quality of any crops grown hereunder is such that it will not return the estimated cost, the Association may refuse to harvest, pack, and sell such crops unless the Grower will advance the estimated charge daily, or shall execute an order authorizing deductions for such charge from other funds due the Grower.

16. In the event the Association shall have so many crops that it shall not have the facilities available for harvesting and packing, and shall be required to have others harvest and pack such produce, the Grower herein shall not be charged for such harvesting and packing any more than the actual costs determined for the year, and the costs for the Association for such harvesting and packing shall be included in determining actual costs. The Association shall, upon sale, deduct the estimated cost from proceeds. 
17. Any unit, item or part of the crops heretofore described which does not conform to those standards and/or grades of quality, size, variety, or condition prescribed by law or established by custom at the place of delivery, or which is damaged or otherwise unfit, is unmarketable. The Association will not be responsible or accountable for unmarketable crops or unmarketable units or parts thereof, either in the field or delivered to it, and may dispose of the same with or without consideration at any time the Association deems fit, and in its discretion the Association may refuse to harvest such crops. The Grower will reimburse the Association in handling, dealing with or disposing of such crops or such units, items, or parts thereof. Any refusal to handle by the Association shall constitute a release and Grower may dispose of any units or parts of crops refused in any manner he shall see fit.

18. Spring crops shall mean all crops harvested between January 1 and August 1, and Fall crops shall mean all crops harvested between August 1 and December 31.

19. There may be some crops herein designated which are not yet planted. There shall be no penalty for not planting any crop herein specified, provided, however, that if the Grower herein fails to plant the acreage herein specified and plants or grows the crop herein specified or any acreage not herein specified at the period for which the crop described herein is to be grown, the Association shall be entitled to such crop so grown to the extent of the acreage herein specified.

20. In the event the Grower shall sell any or all of the crops described in the Appendix hereto, other than in accordance with the terms of this agreement and the By-Laws of the Association, such act will injure the Association to an amount that is and will be impracticable and extremely difficult to determine and fix. For each packed crate sold, delivered, or disposed of by a Grower in violation hereof, such Grower will pay the Association in cash on demand a sum equal to the product of the number of crates so sold multiplied by Association's then estimated cost per unit or crate; at the end of the year in which such crops are sold, such Grower will be entitled on written demand delivered to Association to a refund of the excess of such estimated cost over actual cost on the same basis as a nonviolating Grower. In the event of any such breach or threatened breach, the Association, in addition to damages, should be entitled to an injunction to prevent the further breach thereof and to a decree of specific performance under this contract. The Grower agrees to pay all cost, bond premiums, expenses and attorney's fees if any legal or equitable action is presented by the Association to compel performance of this contract, or to enjoin any breach thereof or to recover damages for any such breach by the Grower. 
21. Neither party hereto shall be liable for any breach hereof caused by fire, theft, strike, civil disturbance, act of God, crop failure, inability to obtain required labor, materials, machinery or transportation facilities, governmental provisions or restrictions, or any other causes (whether or not similar to the foregoing) beyond the control of such party.

22. This agreement is subject to the provisions of the By-Laws and Articles of Incorporation of the Association, and in event any provision or provisions of this agreement are in conflict with the provisions of the By-Laws or Articles of Incorporation of the Association, the provisions of the By-Laws or Articles of Incorporation shall prevail.

23. This agreement shall remain in effect to and including the , and shall be binding on the heirs, executors, administrators, and assigns of the Grower herein. 
SPECIAL PROVISIONS:

IN WITNESS WHEREOF, the parties hereto have hereunto set their hands the day and year first above written.

a non-profit marketing cooperative association

BY

BY

GROWER 


\section{APPENDIX}

Crops included within the terms of this Agreement.

$\underline{\text { SPRING }}$
A. RINDS
B. NO. OF ACRES :
C. APPROXIMATE PLANTING DATE:
D. LOCATION AND DESCRIPTION:

FALL
A. KIND
B. NO. OF ACRES :
C. APPROXTMATE PLANTING DATE:
D. LOCATION AND DESCRIPTION: 


